\title{
Türkiye Ekonomisinde Cari İşlemler Açığının Belirleyicileri: Dönemler Arası Yaklaşım*
}

\section{Determinants of Current Account Deficit in Turkish Economy: An Intertemporal Approach}

\author{
Arş. Gör. Ali Benli ${ }^{1}$ - Prof. Dr. Özgür Tonus ${ }^{2}$
}

Başvuru Tarihi: 23.08.2019

Kabul Tarihi: 18.09.2019

\section{Öz}

Bu çalışmanın temel amacı Türkiye ekonomisinde cari işlemler açı̆̆ına neden olan temel makroekonomik, finansal ve yapısal faktörleri betimsel istatistikler ve ampirik analiz yardımıyla araştırmaktır. Türkiye'de özellikle 2001 krizi sonrasında genişleyen ve kalıcı hale gelen cari işlemler açığı konusundaki endişeler artmıştır. Çalışmada kullanılan ampirik model "dönemler arası" ve "esneklikler" yaklaşımlarının bir sentezi niteliğindedir. Cari işlemler dengesini ulusal gelir, bütçe dengesi, döviz kuru ve faiz oranlarının bir fonksiyonu olarak ele almaktadır. Model kısa ve uzun dönemlik analizlere olanak tanıyan ARDL yaklaşımı ile üç aylık frekanstaki veriler kullanılarak tahmin edilmiştir. Bulgulara göre bütçe dengesi, döviz kuru ve faiz oranı cari işlemler dengesi üzerinde uzun dönemde etkiliyken, kısa dönemde sadece GSYH ve bütçe dengesi etkilidir. Bütçe dengesi ile ilgili bulgular Ricardocu Denklik Hipotezinin Türkiye ekonomisinde geçerli olmadı̆̆ını, İkiz Açık Hipotezinin ise geçerliliğini göstermektedir.

Anahtar Kelimeler: Cari Açık, Tasarruf Açı̆̆ı, Dönemler Arası Yaklaşım, İkiz Açık Hipotezi, $A R D L$

\begin{abstract}
The aim of this paper is to research the fundamental factors which affected Turkey's current account deficit and discuss the external balance via descriptive statistics and an empirical analysis. Concerns over Turkey's current account deficit raised before 2001 crises since the deficit has become large and persistent. The empirical model used in this study is a synthesis of "intertemporal" and "elasticities" approaches to current account balance. The model treats current account as the result of national income, budget balance, exchange rate and interest rate. Empirical model is estimated with quarterly data by using apply ARDL technique which enables short and long run analysis. Findings suggest that budget balance, exchange rate and interest rate are effective in the long run, whereas only national income and budget balance are effective in the

\footnotetext{
* Bu çalışma Prof. Dr. Özgür TONUS’un danışmanlığında yürütülen ve 2018 yılında Anadolu Üniversitesi Sosyal Bilimler Enstitüsünde sunulan Ali BENLİ'nin “Türkiye Ekonomisinde Cari İşlemler Açı̆̆ının Temel Belirleyicileri: 2001 Krizi Sonrası Dönemin Analizi” başlıklı tezinden türetilmiştir.

Anadolu Üniversitesi İ.İ.B.F., alibenli@anadolu.edu.tr, ORCID: 0000-0003-3507-079X

2 Anadolu Üniversitesi İ.̇̇.B.F., otonus@anadolu.edu.tr, ORCID: 0000-0003-0950-3328
} 
short run on current account balance. According to evidence related with budget balance shows that Ricardian Equivalence Hypothesis is not valid but Twin Deficit Theory in Turkish economy over the period.

Keywords: Current Account Deficit, Savings Gap, Intertemporal Approach, Twin Deficit Theory, $A R D L$

\section{Giriş}

Gelişmekte olan ülkelerin büyük ve kalıcı cari açık yapıları bu ekonomiler için makroekonomik kırılganlıkların temel nedenlerinden biridir ve ekonomik büyüme önünde bir kısıt teşkil etmektedir (Blanchard ve Milesi-Ferretti, 2012). Eğer cari açı sürdürülebilir bir yapıda değilse bu ekonomilerde finansal istikrarsızlıklara, dış ödeme güçlüklerine ve nihai olarak finansal krizlere yol açabilir. Yatırımcıların algılarında olumsuz yönde değişimler yaşanması yabancı finansmana bağımlılı̆ı̆ yüksek olan ekonomilerde hızlı ve keskin bir biçimde dış dengesizlik sürecini tetikleyerek bu ekonomiler için ciddi sonuçlara neden olabilir (Brissimis vd., 2012). 2008 yılındaki küresel finansal krizde cari açık problemi olan bazı önemli ekonomilerin yaşadıkları finansman sorunları bu riskleri ortaya koymuştur (Catão ve Milesi-Ferretti, 2014). Bu bakış açısından cari işlemler dengesinin belirleyicilerinin ortaya konması önemli bir konu haline gelmiştir. Milenyum sonrasında cari işlemler dengesini açıklamaya yönelik birçok teorik dönemler arası (intertemporal) model geliştirilmiş̧tir. Dönemler arası yaklaşımın ampirik uygulamaları genellikle temel ulusal gelir denkliğine dayalı modellemelerden oluşmaktadır. $\mathrm{Bu}$ modeller ekonomilerin cari işlemler pozisyonunu ulusal tasarruflar ile yatırımların farkının ve belirli makroekonomik olguların sonucu olarak ele almaktadır.

$\mathrm{Bu}$ çalı̧̧manın temel amacı Türkiye ekonomisinde cari işlemler dengesindeki gelişmeleri açıklayacak uygun bir ampirik bir model oluşturmak ve cari işlemler dengesini etkileyen temel makroekonomik ve finansal faktörleri ortaya koymaktır. Tanımlanan ampirik model "dönemler arası" ve "esneklikler" yaklaşımının bir sentezi niteliğindedir. Ampirik analizin kapsamı 2006-2019 döneminden oluşmaktadır. Dönem başının 2006 olarak belirlenmesinin sebebi 2001 krizinin saptırıcı etkilerinin model dışında bırakılmak istenmesi ve bütçe dengesi verilerinin yeni tanımılla bu tarihte yayınlanmaya başlamasıdır.

Çalışmanın düzeni şu şekildedir: ilk planda Türkiye'de 2000 yllı sonrası dönemde cari açı̆̆ı̆ı gelişimi, yapısı ve temel makroekonomik göstergelerle ilişkisi ele alınacaktır. Sonraki bölümde temel ulusal gelir denkliğinden yola çlkılarak cari işlemler dengesinin belirleyicilerini analiz etmek üzere ampirik bir model tasarlanacaktır. Ardından teorik ve ampirik literatür tartışlacak ve uygun ekonometrik yöntem seçilerek tahmin edilen modele ilişkin ampirik bulgular aktarılacaktır. Sonuç bölümünde ise nihai olarak çalışmanın temel bulguları ve politika önerileri sunulacaktır. 


\section{Türkiye Ekonomisinde Cari İşlemler Dengesinin Dinamikleri}

Bu bölümde 2001 sonrasında Türkiye ekonomisinde cari işlemler açığının yapısı, dinamikleri ve diğer ekonomik göstergelerle ilişkisi aktarılacaktır. Cari işlemler dengesi dış ticaret dengesi, hizmetler dengesi, birincil ve ikincil gelir dengesinin toplamından oluşmaktadır. Dış ticaret dengesi toplam mal ihracatı ile mal ithalatı arasındaki farkı, hizmetler dengesi ekonominin hizmet gelirleri ile giderleri arasındaki farkı ifade etmektedir. Birincil gelir dengesi üretim faktörlerinin yabancılara tahsis edilmesinden doğan gelir ve gider farkından oluşur ve temelde ücret, faiz ve kâr payı ödemelerini kapsar. İkincil gelir dengesi ise karşılıksız gelir transferlerinden oluşan gelir ve gider farkıdır. Şekil 1'de Türkiye'de 2001-2018 dönemi için cari işlemler hesabını oluşturan kalemler gösterilmiştir.

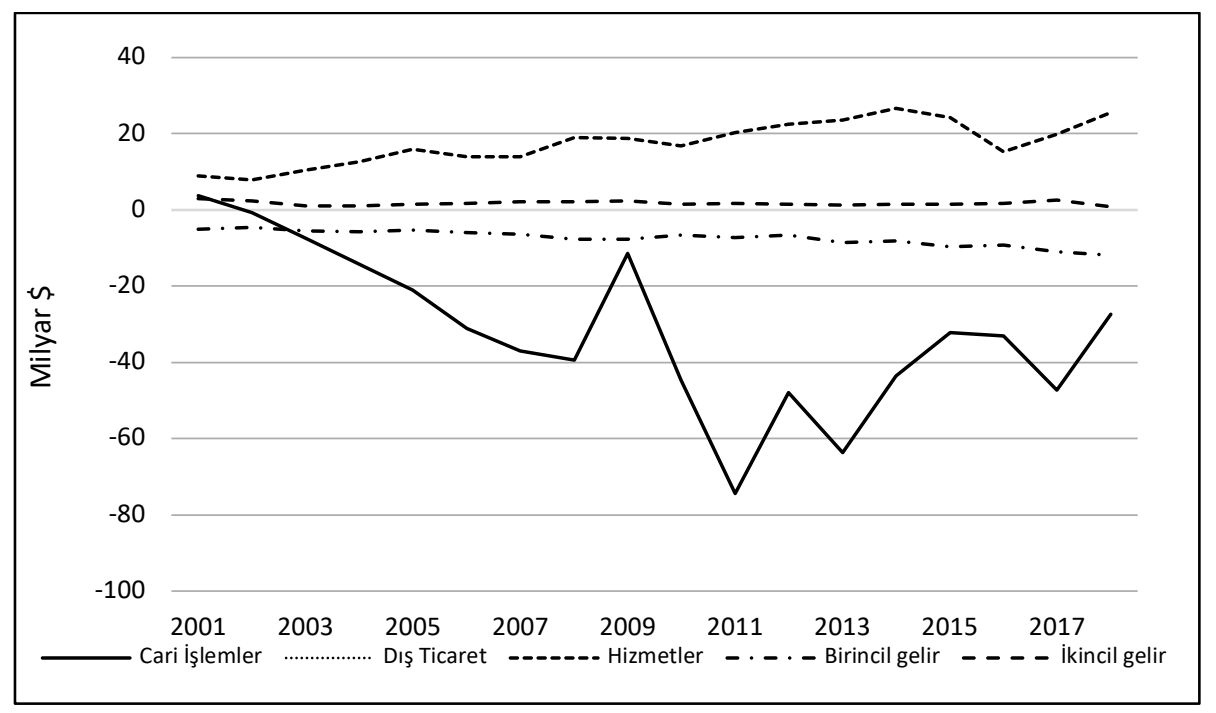

Şekil 1. Cari İşlemler Dengesinin Bileşenleri (Kaynak: TCMB)

Şekilde cari işlemler dengesi ile diş ticaret dengesinin paralel biçimde hareket ettiği net bir şekilde görülmektedir. Buna göre Türkiye'de cari açığ temelde dış ticaret açığı yönlendirmektedir. Diğer kalemler dönem içerisinde oldukça istikrarlı bir seyir izlemektedir. Hizmetler dengesi dönem boyunca pozitif gerçekleşerek dış ticaret açığının yarattığı olumsuzluğun bir kısmını gidermektedir. Ayrıca hizmetler dengesi dönem boyunca artış eğilimindedir ve 2018 yılında 25.6 milyar \$ olarak gerçekleşmiştir. Birincil gelir dengesi ise dönem boyunca negatif gerçekleşerek cari açıkta genişlemeye neden olmaktadır. Birincil gelir dengesi temelde Türkiye'ye yönelik yabancı yatırımların gelirlerinden oluşmaktadır. Birincil gelir dengesindeki açık giderek büyümektedir. 2000 yılında 4 milyar \$ gerçekleşen açık, sürekli artarak 2018 yılında yaklaşık 12 milyar \$ olarak gerçekleşmiştir. 2018 yılında cari açığın yaklaşık \%43.5’i birincil gelir dengesi açığından oluşmaktadır. Bu durum Türkiye’ye yabancı sermayeyi getirmenin maliyetinin oldukça yüksek olduğunu göstermektedir. İkincil gelir dengesinin ise dış denge içerisindeki payı oldukça küçüktür. Yine de dönem boyunca pozitif gerçekleşerek cari dengeyi olumlu yönde etkilemiştir. 


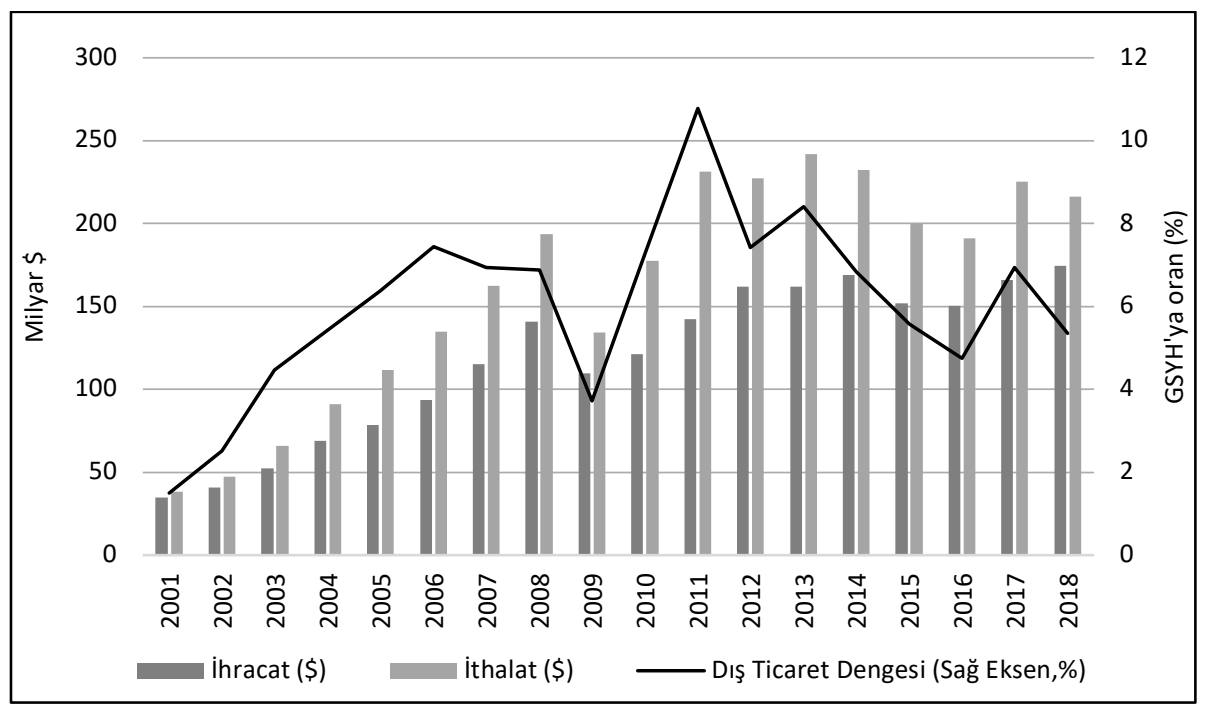

Şekil 2. İhracat, IIthalat ve Dış Ticaret Dengesi (Kaynak: TCMB)

Şekil 2'de Türkiye'nin 2001-2018 dönemine ait ihracat, ithalat ve dış ticaret dengesi sunulmuştur. Dönem boyunca ithalat ihracatın üzerinde gerçekleşerek dış ticaret açı̆̆ oluşmuştur. Özellikle 2009 krizi sonrasında ithalat hızla artarken ihracatın artış hızı daha düşük kalmış ve dış ticaret açığ giderek artmıştır. Kriz dönemlerinde hem ithalat hem de ihracat önemli miktarda azalmıştır. Türkiye’nin ithalat kalemleri içerisinde enerji çok önemli bir pay tutmaktadır. Toplam ithalat içerisinde dönem ortalaması olarak enerjinin payı yaklaşık olarak \%20'dir. Bu nedenle enerji fiyatlarındaki değişmeler Türkiye'de ithalat ve dolayısıyla cari işlemler dengesi üzerinde önemli bir etkiye sahiptir.

Tüm gelişmekte olan ülkelerde olduğu gibi Türkiye ekonomisinde de yatırımların finansmanında dış kaynağa ihtiyaç duyulmaktadır. Bu durum ekonomik büyüme ile cari açık arasında aynı yönlü bir ilişkiye neden olmaktadır. Şekil 3’te 2001-2018 döneminde büyüme oranı ile cari açık ilişkisi yer almaktadır.

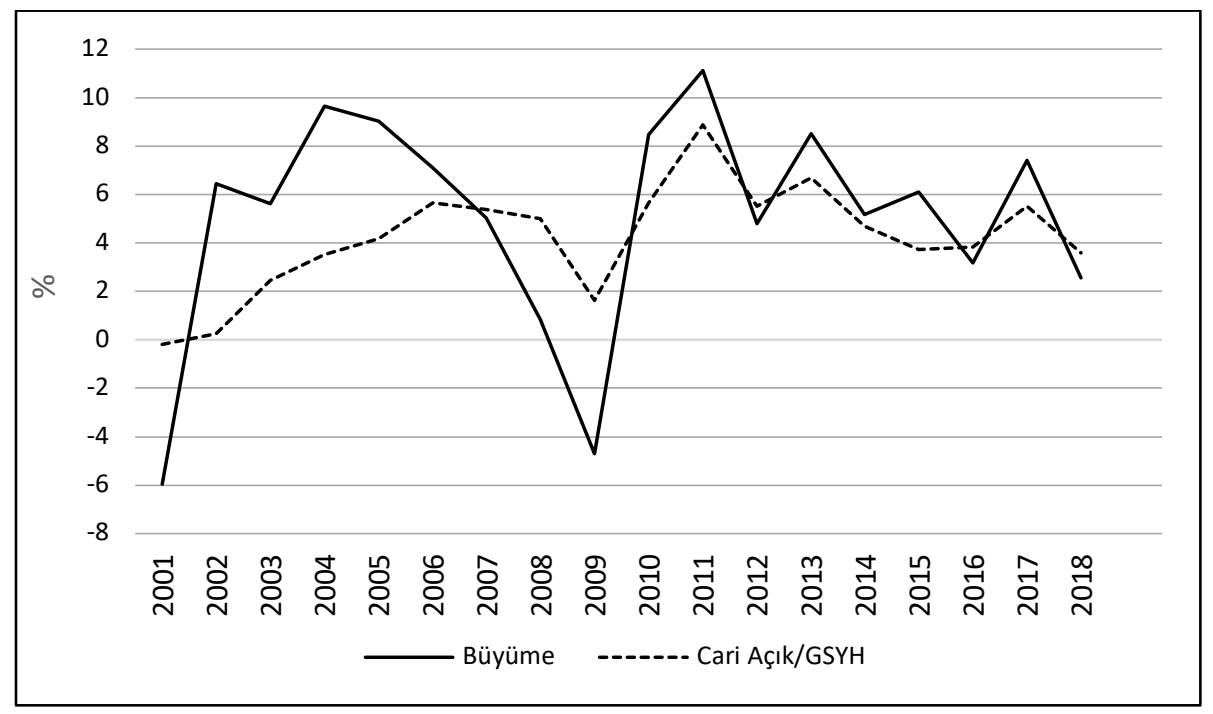

Şekil 3. Büyüme ve Cari Açık İlişkisi (Kaynak: TCMB, TÜİK) 
Şekile göre büyüme ile cari açık birlikte hareket etmektedir. Nedenselliğin cari açıtan ekonomik büyümeye mi yoksa ekonomik büyümeden cari açığa mı doğru olduğunu söylemek güçtür. Genel olarak çift yönlü bir nedensellikten söz edilebilir. Cari açı̆̆ın arttığı dönemlerde ekonomik büyüme hızı da artmakta, cari açığın azaldığı dönemlerde ise ekonomik büyüme yavaşlamaktadır.

Büyüme cari açık ilişkisinin nedeni temelde Türkiye ekonomisinde yurt içi tasarrufların ekonomik büyümeyi finanse edecek seviyede olmaması nedeniyle ekonomik büyümenin dış kaynaklar yoluyla finanse edilmesidir. Bu nedenle Türkiye'de ekonomik büyüme sermaye hareketlerine bağımlı bir haldedir (Boratav, 2015, s. 214). Ekonomik büyüme ile cari açık arasındaki güçlü ilişki nedeniyle, Türkiye'de dış kaynak hareketlerinin neden olabileceği ani duruş veya sermaye çıkışları ekonomiyi kırılgan hale getirmektedir (Özmen, 2004). Çünkü sermaye çıkışları beklentilerin bozulmasına neden olarak iç talepte daralmaya neden olabilir. Türkiye ekonomisinde sürdürülebilir bir büyüme için dış kaynaklara bağımlılığın azaltılarak, büyümenin yurt içi tasarruflardaki artı̧s yoluyla finanse edilmesi gerekmektedir (YASED, 2011, s. 5).

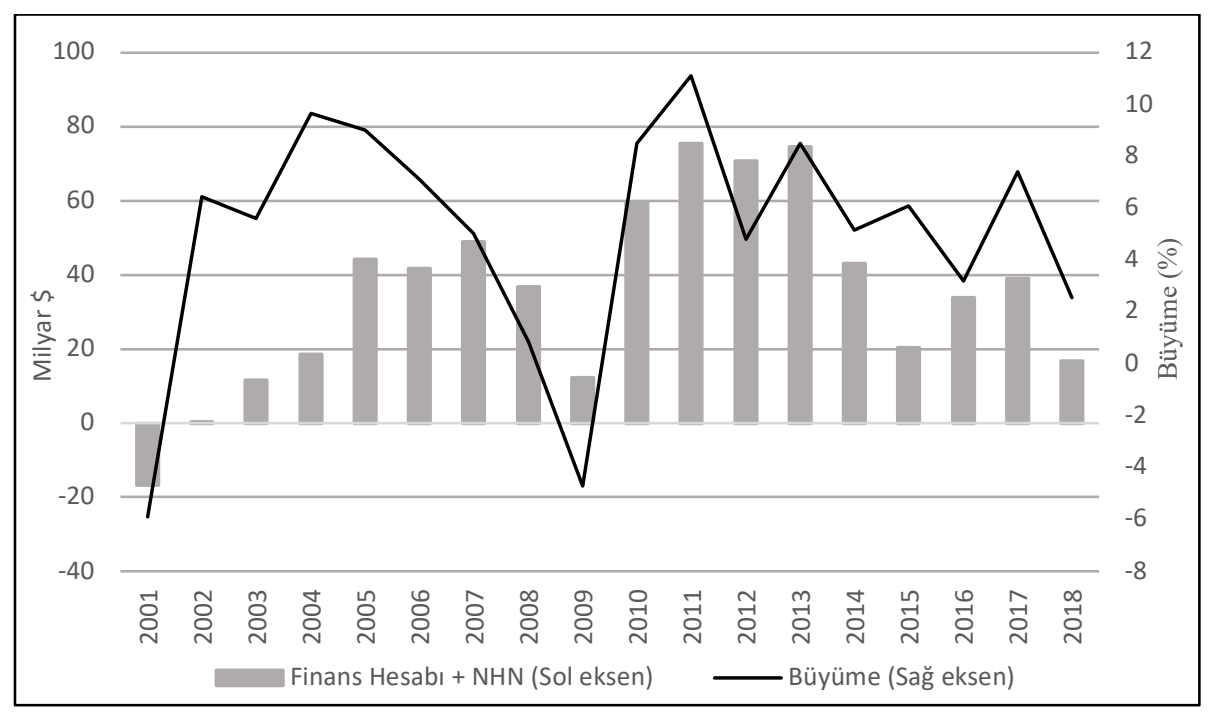

Şekil 4. Yabancı Kaynak Girişi ve Büyüme İlişkisi (Kaynak: TCMB, TÜİK)

Şekil 4'te Türkiye'nin 2001-2018 döneminde finans hesabı ve NHN toplamı ve büyüme oranı gösterilmiştir. NHN, finans hesabına yansımayan sermaye hareketlerini temsil ettiği için, toplam sermaye giriş veya çıkışlarını göstermek üzere finans hesabına eklenmiştir. Şekil 4'e göre ekonomiye dış kaynak girişlerinin arttığı dönemlerde büyüme hızı da artmakta, sermaye çıkışları veya sermaye girişlerinde azalmanın olduğu dönemlerde ise büyüme oranı yavaşlamaktadır. Özellikle 2001 ve 2009 krizlerinde meydana gelen sermaye çıkışlarının büyüme hızını negatife dönüştürdüğü gözlenmektedir. 2018'de sermaye girişi önemli miktarda azalmış bununla birlikte ekonomik büyüme de \%2.5 düzeyine düşmüştür. Büyüme oranının dönemdeki en yüksek düzeyine ulaştığı 2011 yılında ise neredeyse 75 milyar dolar sermaye girişi gerçekleşmiştir. $\mathrm{Bu}$ ilişki ekonominin dış kaynak girişlerine hassasiyetini göstermektedir. 
Böylesi bir yapı da ekonominin kırılganlık düzeyini artırmakta ve olası ani duruşlar ya da sermaye çıkışları durumunda ekonomiyi krizlere karşı savunmasız hale getirmektedir.

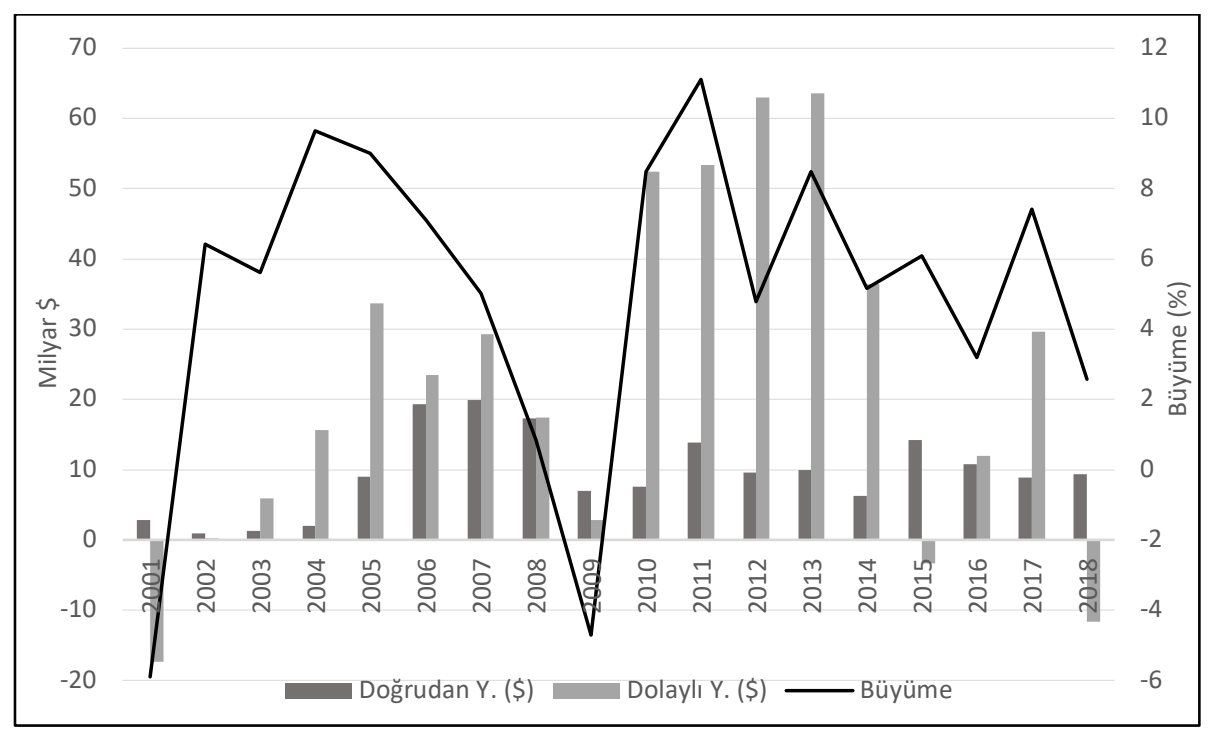

Şekil 5. Doğrudan ve Dolaylı Yatırımların Büyüme ile İlişkisi (Kaynak: TCMB, TÜIK)

Şekil 5’te dış finansmanın türü ile büyüme oranı ilişkilendirilmiştir. Pozitif sütunlar net sermaye girişlerini ve negatif sütunlar net sermaye çıkışlarını göstermektedir. Doğrudan yatırımlar uzun vadeli sermaye hareketlerini ifade ederken, dolaylı yatırımlar ise portföy yatırımları ve diğer yatırımların toplamından oluşan kısa vadeli sermaye hareketlerini temsil etmektedir. 2005-2009 döneminde doğrudan yatırım girişleri ile dolaylı yatırım girişleri birbirine yakınken, küresel kriz sonrası dönemde dolaylı yatırımlar doğrudan yatırımların yaklaşık dört katı üzerinde gerçekleşmiştir. Bu bilgiye göre Türkiye ekonomisi için kısa vadeli yatırımların ağırlığı giderek artmıştır, özellikle küresel krizden sonra büyüme ile kısa vadeli yatırımlar arasındaki ilişki daha belirgin hale gelmiştir. Nitekim 2018 yılında kısa vadeli yatırımlarda meydana gelen ciddi çıkış büyüme oranının \%2.5 düzeyine gerilemesine neden olmuştur. Şekile göre dönem içerisinde doğrudan yatırımlar dolaylı yatırımlara göre daha fazla dalgalanma göstermektedir. Kısa vadeli sermayenin dış finansmandaki payının yüksek olması cari açığın neden olduğu kırılganlığın artmasına neden olmaktadır.

Şekil 6'da Türkiye ekonomisinde 2001-2018 döneminde cari açık, tasarruf ve yatırımların GSYH'ya oranları gösterilmiştir. Dönem içerisinde tasarruf oranlarının istikrarlı bir seyir izlediği ve eğimin artan olduğu görülmektedir. Küresel kriz öncesi ortalama tasarruf oranı \%22.1 iken, kriz sonrası bu oran ortalama olarak \%23.8'e yükselmiştir. 2018 yılında gerçekleşen tasarruf oranı \%25.1'dir. Giderek artan tasarruf oranları Türkiye için olumlu bir gelişme olarak değerlendirilebilir. Yatırım oranları ise dönem boyunca oldukça yüksek dalgalanmalar göstermektedir. Buna rağmen dönem içerisinde artan trende sahip olduğu görülmektedir. Küresel kriz öncesi ortalama yatırım oranı \%25 iken, kriz sonrası bu oran ortalama olarak \%29.3'e yükselmiştir. 2018 yılında gerçekleşen yatırım oranı \%30.7'dir. 


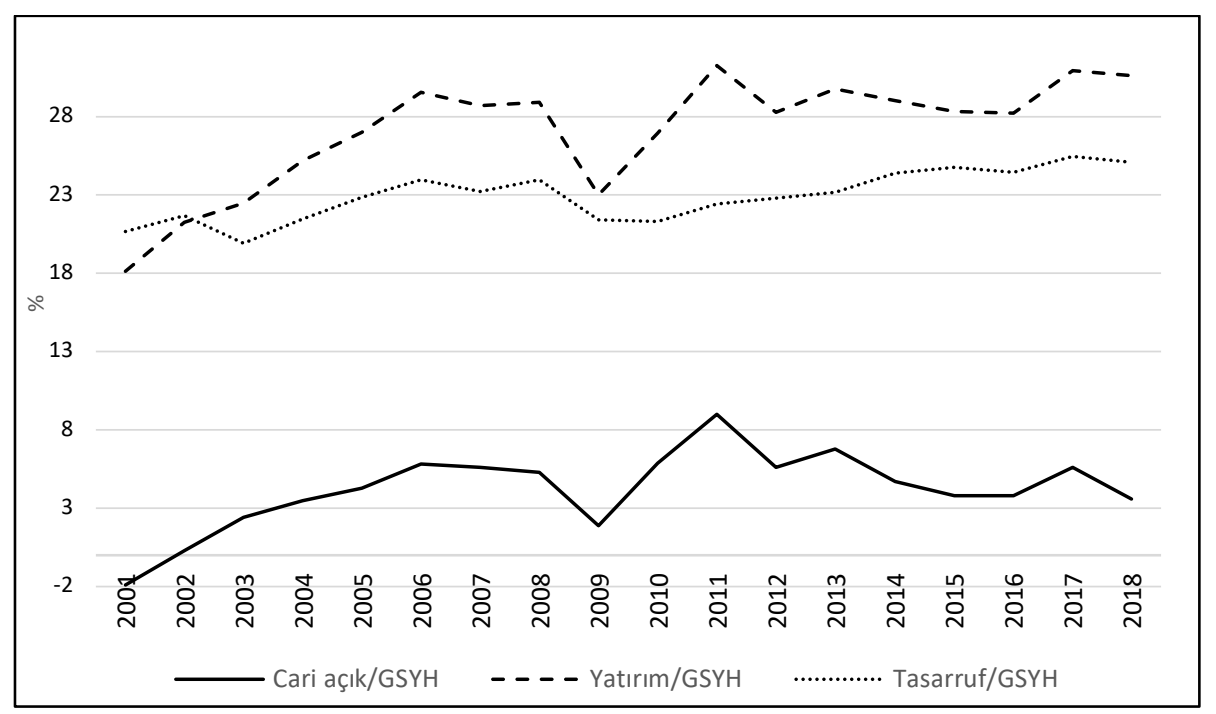

Şekil 6. Türkiye Ekonomisinde Yatırım, Tasarrufve Cari Açık (Kaynak: Dünya Bankası)

Cari açık ise dönem boyunca \%4 etrafında istikrarlı bir seyir izlemektedir. İki önemli kriz döneminde ciddi oranda azalma kaydetmiştir. 2001 krizinde dönemin tek cari fazla durumu (\%1.9) gerçekleşmiştir. 2009 krizinde ise yaklaşık \%2’ye kadar düşmüştür. Şekilde cari açı ile yatırım oranlarının birlikte hareket ettiği gözlenmektedir. Buna göre cari açı̆̆ı temelde yatırımlar yönlendirmektedir. Yatırımlardaki artış dönemlerinde cari açık da yükselme kaydetmektedir. Bu durum Türkiye'deki cari açık-büyüme ilişkisini yatırımlar açısından ortaya koymaktadir.

Şekil 7, Türkiye ekonomisinde reel döviz kuru ile ihracat ve ithalatın ilişkisini göstermektedir. Dönem boyunca 2018'deki sapma hariç ihracatın GSYH'ya oranı ortalama olarak \%17'dir ve bu ortalamanın etrafında seyretmektedir. İthalat ise artan fakat istikrarsız bir yapı izlemektedir. Reel efektif döviz kuru endeksine göre Türk lirası, 2001-2007 döneminde hızla değer kazanırken 2007 yılından sonra hızla değerini kaybetmiştir.

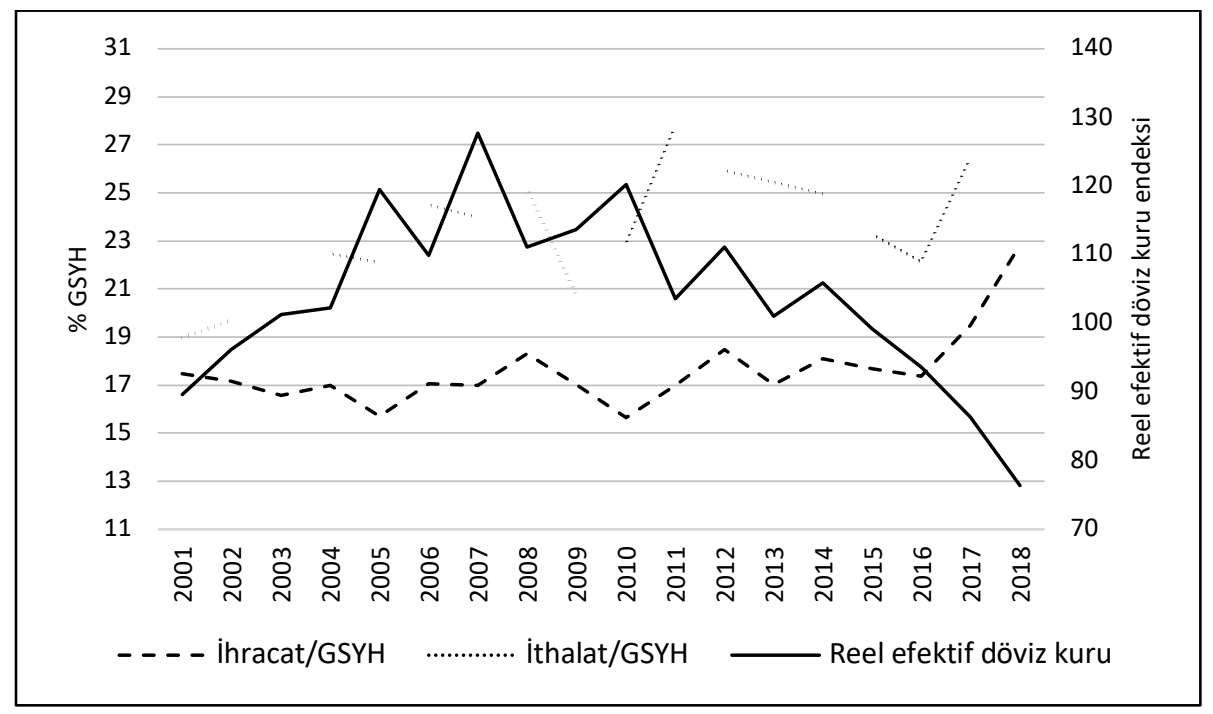

Şekil 7. Reel Efektif Döviz Kuru ve Dış Ticaret İlişsisi (Kaynak: TCMB) 
İhracat döviz kurundaki değişimlerden oldukça az etkilenirken, ithalat döviz kurundaki değişmelere daha fazla tepki vermektedir. Türk lirasının değer kazandığı dönemlerde ithalattaki artı̧s ihracattaki azalışlardan göreli olarak fazla olmuştur. Bu durum Türkiye'nin diş ticaret yapısından kaynaklanmaktadır. Türkiye'nin toplam ithalatı içerisinde ara mallarının payı dönem ortalaması olarak yaklaşık \%72 ve tüketim mallarının payı \%12'dir. Toplam ihracat içerisinde ara malı ihracatının payı \%46 iken, tüketim mallarının payı \%43’tür. Buna göre Türkiye dış dünyadan yoğun bir şekilde ara malı ithal ederken bunun karşılığında daha az ara malı ihracatı ve daha fazla tüketim malı ihracatı gerçekleştirmektedir. Türk lirasının değer kazandığı dönemlerde sanayi üretimini artırabilmek için ara malı ithalatı dolayısıyla toplam ithalat artmaktadır fakat tüketim malı ihracatı aynı hızla azalmamaktadır.

\section{Türkiye'de Cari İşlemler Dengesinin Belirleyicilerinin Modellenmesi}

Cari işlemler hesabı bir ekonominin dış dünya ile gerçekleştirdiği mal ticaretine ilişkin ithalat ve ihracatını, hizmet gelir ve giderlerini, karşılıklı faktör geliri ödemelerini ve niteliği sermaye transferi olmayan karşlıksız transfer ödemelerini kapsar. Cari işlemler hesabının bileşimi ve bakiyesi büyüme, enflasyon ve işsizlik gibi makroekonomik olgular üzerinde etkili olduğu oldukça önemlidir (Pugel, 2016, 370). Bir ekonominin cari işlemler açı̆̆ı vermesi bu ekonominin gelirinden daha fazla harcama yapması anlamına gelir. Başka bir ifadeyle bu ekonomide gerçekleştirilen yatırımlar iç tasarruflardan fazladır (Appleyard, 2015, 471). Bunu temel ulusal gelir denkliği yardımıyla şu şekilde açıklayabiliriz.

$$
G D P=C+I+G+X-M
$$

Eşitlik l'e göre gayri safi yurt içi hasıla (GDP), yurt içi hanehalkı mal ve hizmet tüketimi (C), yurt içi yatırımlar (I), kamu harcamaları (G) ve mal ve hizmet ihracatının (X) toplamından mal ve hizmet ithalatının (M) çıkarılmasıyla elde edilmektedir. Gayri safi milli hasıla (GNP) ise GDP’ye net dış alem faktör gelirlerinin, başka bir ifadeyle birincil gelir dengesinin (BPI) eklenmesiyle elde edilir. Net dış alem faktör gelirleri, üretim faktörlerinin başka yabancı yerleşiklere kullandırılmasından sağlanan gelirleri ifade etmektedir. Bunlar işçi gelirleri ve yatırım gelirleri şeklinde olabilir.

$$
G N P=C+I+G+X-M+B P I
$$

Milli harcanabilir gelir (GNDY) ise gayri safi milli hasılaya (GNP) net karşılıksız transferlerin, başka bir ifadeyle ikincil gelir dengesinin (BSI) eklenmesiyle elde edilir. Buna göre harcanabilir milli geliri (GNDY) elde etmek üzere 2 numaralı eşitliğin her iki tarafına ikincil gelir dengesini (BSI) ekleyelim.

$$
G N D Y=C+I+G+X-M+B P I+B S I
$$

Eşitliğin sağ tarafındaki terimler $(X-M+B P I+B S I)$ sırasıyla mal ve hizmet ihracatı, (eksi) mal ve hizmet ithalatı, birincil gelir dengesi ve ikincil gelir dengesinin toplamıdır. $\mathrm{Bu}$ toplam cari işlemler dengesine (CAB) eşittir. Bu düzenlemeyi gerçekleştirirsek 4 numaralı eşitlik elde edilir.

$$
G N D Y=C+I+G+C A B
$$


Harcanabilir milli gelirden (GNDY) toplam yurtiçi harcamalar $(\mathrm{C}+\mathrm{G})$ çıkarıldığında toplam tasarruf (S) elde edilir.

$$
\begin{aligned}
& G N D Y-(C+G)=I+C A B \\
& S=I+C A B
\end{aligned}
$$

Eşitliği yatırım ve tasarruf farkını gösterecek şekilde düzenleyerek yeniden ifade edelim.

$$
C A B=S-I
$$

Eşitlik 6’ya göre cari işlemler dengesi (CAB), ulusal tasarruflar (S) ile ulusal yatırımların (I) farkına eşittir. Buna göre bir ekonomide eğer ulusal tasarruflar yatırımlardan büyük ise cari işlemler hesabı pozitif olur ve cari fazla gerçekleşir, aksine yatırımlar tasarruflardan büyük ise cari işlemler hesabı negatif olur ve cari açık gerçekleşir. Bir ekonomide yurt içi tasarruflar, yurt içi yatırımları finanse etmekte yetersiz kalıyorsa söz konusu tasarruf açı̆̆ı ekonomiye dış kaynak girişleri ile karşılanıyor demektir. Bu durumda finans hesabı bakiyesi pozitif olacağından cari işlemler dengesi de negatif olur. Aksine ekonomide yurt içi tasarruflar yatırımlardan büyük ise, söz konusu tasarruf fazlası ile yabancıların yatırımları finanse ediliyor anlamına gelir. $\mathrm{Bu}$ durumda finans hesabı bakiyesi negatif olacağından cari işlemler dengesi de pozitif olur.

Ekonomideki toplam tasarruflar, kamu ve özel kesim tasarruflarının toplamından $\left(S=S^{G}+\right.$ $\left.S^{P}\right)$ ve toplam yatırımlar, kamu ve özel kesim yatırımlarının toplamından $\left(I=I^{G}+I^{P}\right)$ oluşur. Eşitlik 6 bu bilgiye göre ifade edildiğinde;

$$
\begin{aligned}
& C A B=\left(S^{G}+S^{P}\right)-\left(I^{G}+I^{P}\right) \\
& C A B=\left(S^{P}-I^{P}\right)+\left(S^{G}-I^{G}\right)
\end{aligned}
$$

Cari işlemler hesabı özel kesim tasarruf-yatırım dengesi ile kamu tasarruf-yatırım dengesinin toplamından oluşmaktadır. Buna göre cari açık ekonomideki özel kesim tasarruf açığı ile bütçe açı̆̆ının bir sonucudur.

Dönemler arası yaklaşım özel kesime ait tasarruflar ve yatırımların, geleceğe dönük dinamik kararlardan etkilendiğini öne sürerek cari işlemler dengesini açılamaya yönelik literatüre önemli bir katkı sağlamıştır. Bu kararlar beklenen gelir artışı, faiz oranı, kamu harcamaları ve döviz kurları gibi birçok faktörden etkilenmektedir. Bu değişkenler üzerine oluşan beklentiler yatırım ve tasarruf kararlarını etkilemektedir. Bu süreçte cari işlemler dengesi, söz konusu değişkenlerde meydana gelen şoklara tepki vermektedir (Obstfeld ve Rogoff, 1994, s. 2). Bu çalışmada tahmin edilecek model kurgulanırken dönemler arası yaklaşımın bu çıkarımları esas alınmıştır.

Özel kesim tasarruf açığını ulusal gelir (GDP), döviz kuru (ER) ve reel faiz oranının (RIR) bir fonksiyonu olarak yazalım.

$$
\left(S^{P}-I^{P}\right)=f(G D P, E R, I R)
$$


Kamu tasarruf dengesini de vergi gelirleri (T) ile kamu harcamalarının (G) farkı, bütçe dengesi $(T-G)$ olarak ifade edebiliriz. Bunu kısaca BUD ile ifade edelim.

$$
S^{G}-I^{G}=T-G=B U D
$$

Dolayısıyla cari açığı şu şekilde modelleyebiliriz.

$$
C A B=f(G D P, E R, I R)+B U D
$$

Bütçe açığını da dışsal bir değişken olarak fonksiyona dahil ederek cari işlemler dengesini nihai olarak şu şekilde modelleyebiliriz.

$$
C A B=F(G D P, B U D, E R, I R)
$$

Yukarıdaki eşitliğe göre cari işlemler dengesi, ulusal gelir, bütçe dengesi, döviz kuru ve faiz oranının bir fonksiyonudur. Fonksiyonda yer alan bağımsız değişkenlerin cari işlemler dengesi üzerindeki etkilerinin nasıl olacağı teorik ve ampirik literatür çerçevesinde aktarılacaktır.

\section{Literatür}

Bu bölümde cari işlemler açığının nedenlerini açıklamaya yönelik teorik ve ampirik literatür özetlenecektir. Bir önceki bölümde belirlenen bağımsız değişkenler ile cari işlemler dengesi arasındaki ilişki aşağıda başlıklar halinde tartışılmıştır.

\section{Ulusal Gelir}

Ulusal gelirdeki değişmeler, cari işlemler dengesini hem yatırım hem de tasarruflar kanalıyla etkileyebilir. Ulusal gelirdeki pozitif yönlü değişmeler ekonomik büyüme olarak adlandırılır. Chinn ve Prasad (2003) ekonomik büyümenin harcanabilir gelirdeki değişimin bir göstergesi olarak yorumlanabileceğini, böylece hanehalkı tasarrufunu etkileyeceğini savunmaktadır. Fakat büyümenin tasarruflar üzerindeki etkisi iki yönde de olabilir. Eğer hanehalkı yüksek büyüme oranlarını sürekli gelirlerindeki bir artış olarak yorumlarsa, bu durum tüketim harcamalarının ve ithalatın artmasına neden olur. Böylece hanehalkı tasarrufları azalır. Aksine, eğer hanehalkı ekonomik büyümeyi geçici olarak yorumlarsa tasarruflarını artırır (Ciocyte ve RojasRomagosa, 2015).

Yatırımlar açısından bakıldığında ise yüksek büyüme oranı, verimlilik artışı ile ilişkilendirilebilir. Bu nedenle, ekonomik büyüme ile yatırımlar arasında pozitif bir ilişki beklenmektedir. Sonuç olarak, büyümenin tasarruflar ve yatırımlar üzerinde yarattı̆̆ı birbirine zit etkiler nedeniyle cari denge üzerindeki net etkisi teorik olarak belirsizdir. Fakat ampirik çalışmalar genel olarak ekonomik büyüme ile cari işlemler dengesi arasında negatif bir ilişki tespit etmektedir.

Gelir ayrıca ekonomik gelişmişlik düzeyi ile de ilişkilendirilebilir. Ekonomik kalkınmanın erken aşamalarındaki ülkeler, daha ileri aşamalardaki ülkelere göre daha fazla yatırıma ihtiyaç duyarlar ve bu yatırımları çoğunlukla dış borçlanma ile finanse ederler (Obstfeld ve Rogoff, 2002). Erken aşamadaki ülkeler, gelişim aşamaları hipotezine göre (stage of development hypothesis) yoğun bir biçimde sermaye ithal ettikleri için cari açık verirler. Bu ülkeler gelişmiş ülkelerin gelir düzeyine yaklaştıkça cari dengelerinde iyileşme gerçekleşmesi beklenir. 
Kalkınmanın ileri düzeylerine ulaştıklarında ise cari fazla verirler. Hipoteze göre söz konusu ülkenin geliri ile gelişmiş ülkelerin geliri arasındaki fark büyüdükçe, ülkenin cari açı̆̆ının da büyümesi beklenir (Chinn ve Prasad, 2003). Lee vd., (2008) ise aynı gelişmişlik düzeyindeki ülkeler arasında ekonomik büyümesi daha hızlı olan ülkelerin cari işlemler açığının daha fazla olacağını savunmuşlardır.

\section{Bütçe Dengesi}

Bütçe dengesi ile cari işlemler arasındaki ilişki temelde ekonomideki hanehalklarının Ricardocu ya da Keynesci davranış biçimine sahip olmalarına bağlıdır. Keynesci model genişletici maliye politikalarının sonucunda oluşan yüksek bütçe açılarının, harcanabilir geliri artırdığını böylece tüketimin yükselerek tasarrufların düştüğünü varsayar. Tüketimde artış ve tasarruflarda azalma yaratan bu değişim de cari işlemler dengesinde bozulma yaratır. Keynesci modelin bu görüşü "ikiz açıklar" hipotezi ile uyumludur. İkiz açıklar hipotezine göre geniş bütçe açıklarına genellikle geniş cari açık eşlik eder. İkiz açıklar kavramı ilk defa Feldstein $(1985,1987)$ tarafından 1980’lerdeki ABD’nin bütçe açı̆̆ı ve cari açığı arasındaki bağlantıyı açıklamak üzere ortaya atılmıştır.

Salvatore (2006) maliye politikaları ile cari denge arasındaki ilişkiyi açıklayabilmek için ödünç verilebilir fonların arzı ve talebini kullanarak ikiz açıklar hipotezine teorik çerçeve kazandırmıştır. Salvatore'a göre bütçe açığının beklenen etkileri reel faiz oranında artış, ulusal paranın değerlenmesi ve cari dengenin bozulmasıdır. Böylece bütçe dengesi ile cari denge arasında pozitif bir ilişki beklenmektedir. Ayrıca konuyla ilgili yapılan önemli çalışmalar da söz konusu pozitif ilişkinin anlamlı olduğunu doğrulamışlardır (IMF, 2013).

Eğer tüketiciler Ricardocu davranış biçimine sahipse ikiz açık hipotezi geçerli olmayabilir. Ekonomik birimler kamunun mali durumunun sürdürülebilir olmadığını düşünürlerse, gelecekte vergilerin artacağı veya kamu harcamalarının azalacağı beklentisine girerler. Bu beklentiler, gelecekte ekonomik birimlerin harcanabilir gelirlerinin ve dolayisiyla tüketimlerinin azalacağı anlamına gelir. Fakat birimler uzun vadede tüketim düzeylerini korumak isterler. Dolayısıyla birimler bugünkü kamu harcamalarındaki artıştan kaynaklı geçici gelir artışını sürekli gelirlerinde bir artış olarak görmezler. Devletin gelecekte faiziyle birlikte vergi olarak geri alacağı düşüncesiyle bu paraları zamanı geldiğinde devlete iade etmek üzere saklarlar. Böylece tüketim değişmez ve sadece ihtiyati tasarruflar artar. Sonuç olarak artan bütçe açığı kadar tasarruflar artar ve bütçe açıkları ile cari açık arasında bir ilişki yoktur (Brissimis vd., 2012, s. 79).

Ricardocu denklik hipotezi temelli dönemler arası yaklaşım modelleri de bütçe açığının artmasının özel tasarruflarda meydana gelecek artışla dengeleneceğini ve böylece cari dengenin değişmeyeceğini savunur (Glick ve Rogoff, 1995; Obstfeld ve Rogoff, 1994).

Bazı dönemler arası yaklaşım modelleri de iki tip ekonomik birim olduğunu varsaymaktadır: Harcayan (spender) hanehalkı ve tasarruf eden (saver) hanehalkı. Bu birimlerin sürekli gelirlerine göre harcama yaptıkları ve tüketimlerini dönemler arasında ikame edebildikleri varsayılmaktadır (Bussière, Fratzscher, ve Müller, 2010). Bu bakış açısından, bütçe dengesinin 
cari işlemler dengesi üzerindeki etkisi negatif yönlüdür ve etkinin şiddeti ekonomideki "Ricardo hanehalkı"nın payına bağlıdır.

Öte yandan cari işlemler dengesinden bütçe açıklarına doğru da bir nedensellik söz konusu olabilir. Önceki bölümlerde gelişmekte olan ekonomilerde cari açıktaki azalmaya dış kaynak bağımlılığı nedeniyle ekonomik büyüme hızındaki yavaşlamanın eşlik ettiği açıklanmıştı. Ekonomik büyüme hızının azalması vergi gelirlerinde de azalmaya neden olarak bütçe açı̆̆ının artmasina neden olabilir.

\section{Reel Döviz Kuru}

Hem teorik hem de ampirik çalışmalar Marshall-Lerner koşulunun geçerli olması varsayımı altında reel döviz kurundaki yükselişin, ihraç mallarını yabancılar açısından daha ucuz hale getireceğinden, ihracatı artıracağını; aynı zamanda ithal mallarını ülke yerleşikleri açısından pahalılaştıracağından, ithalatı azaltacağını; böylece cari açığı giderici etki yaratacağını savunmaktadır. Kurdaki yükselmenin cari işlemler dengesi üzerinde yaratacağı etkinin derecesi ise esneklikler yaklaşımında bahsedilen ithalat ve ihracat mallarının talep esnekliklerine bağlıdır (Calderón vd., 2007; Hasanov ve Senhadji, 2008). Öte yandan, döviz kurunun düşmesi de ülkenin uluslararası rekabet gücünü olumsuz etkilediğinden hem cari dengede bozulmaya neden olmakta hem de cari açı̆̆ın sürdürülebilirliğini olumsuz etkilemektedir. (Calderón vd., 1999).

\section{Esneklikler Yaklaşımı}

Esneklikler yaklaşımı uluslararası iktisat literatüründeki en eski teorilerden biridir. Sabit kur rejiminin yaygın olduğu dönemlerde cari işlemler dengesizlikleri devletlerin sabit kur rejimi uygulamalarıyla ilişkilendirilmekteydi. Sabit kur rejiminde, eğer yabancı paranın fiyatı $(E R)$ çok düşük olarak belirlenmişse ithalat nispi olarak ucuz ve ihracat pahalı olur, böylece cari açık meydana gelir. Esneklikler yaklaşımının temel sorusu şudur: Eğer bir ülke cari açık veriyorsa hangi koşullar altında ulusal paranın devalüe edilmesi cari açığı azaltır? Daha sonrasında esnek kur rejimlerinin yaygınlaşmasıyla birlikte, model; devletlerin cari açığı azaltmak için izledikleri kur yükseltme politikalarının etkinliğini değerlendirmek için kullanılmıştır (Husted ve Melvin, 2013, s. 310). Devalüasyonun hangi koşullar altında cari açığı gidermede başarılı olacağı ilk olarak A. Marshall ve A. P. Lerner tarafından formüle edilmiştir.

$$
e_{m}+e_{x} \geq 1
$$

Denklemdeki $e_{m}$ ithal malına olan yurt içi talep esnekliğini, $e_{x}$ ihraç malına olan yurtdışı talep esnekliğini göstermektedir. Koşula göre, talep esneklikleri toplamının birden büyük olması halinde devalüasyon dış ticaret açı̆̆ını giderici etki yaparken revalüasyon ise dış ticaret fazlasını giderici etki yapmaktadır. Geniş anlamda, talep esneklikleri toplamı 1'den ne derece büyükse kurda meydana gelen değişmelerin dış dengeyi sağlayıcı etkisi o derece güçlü olur (Seyidoğlu, 2017, s. 449).

Marshall-Lerner koşulu iki varsayıma dayanmaktadır. Birinci varsayıma göre diş ticaret başlangıçta dengededir. Yani ithalat düzeyi ile ihracat düzeyi başlangıçta birbirine yakın veya 
eşittir. İkinci varsayıma göre dış ticarete konu olan mallarının arz esneklikleri sonsuzdur (Karluk, 2009, s. 601).

Esneklikler yaklaşımının ardındaki temel fikir, devalüasyonun cari denge üzerinde yaratacağı etkinin ihracata ve ithalata olan talep esnekliğine bağlı olmasıdır. Devalüasyon dış ticareti fiyat ve hacim etkisi aracılığıyla etkilediğinden kısa vadede fiyat etkisinin ağır basması beklenir. Bu yüzden devalüasyonun hemen ardından cari işlemler dengesinde bir bozulma ortaya çlkabilir (Stokjov, 2016, s. 20).

\section{J-eğrisi Etkisi}

Salvatore (2013, s. 519) kısa vadede talep esnekliklerinin uzun vadeye nazaran daha küçük olacağını belirtmektedir. Ayrıca devalüasyonun hemen ardından ithal malların ulusal para cinsinden fiyatının, ihraç malı fiyatına göre daha hızlı artma eğiliminde olduğunu öngörmektedir. $\mathrm{Bu}$ sebeplerden devalüasyonun hemen ardından cari dengenin kötüleşebileceğini fakat bundan bir süre sonra da iyileşmeye başlayacağını belirtmiştir. Zamanla ihracat hacmi arttıkça ve ithalat hacmi azaldıkça ve bununla birlikte ihraç malı fiyatları, ithal malı fiyatlarına yakınlaştıkça cari dengede başlangıçta meydana gelen bozulma giderilir ve cari denge iyileşmeye başlar. Cari dengede meydana gelen bu süreci J-eğrisi etkisi olarak tanımlanır.

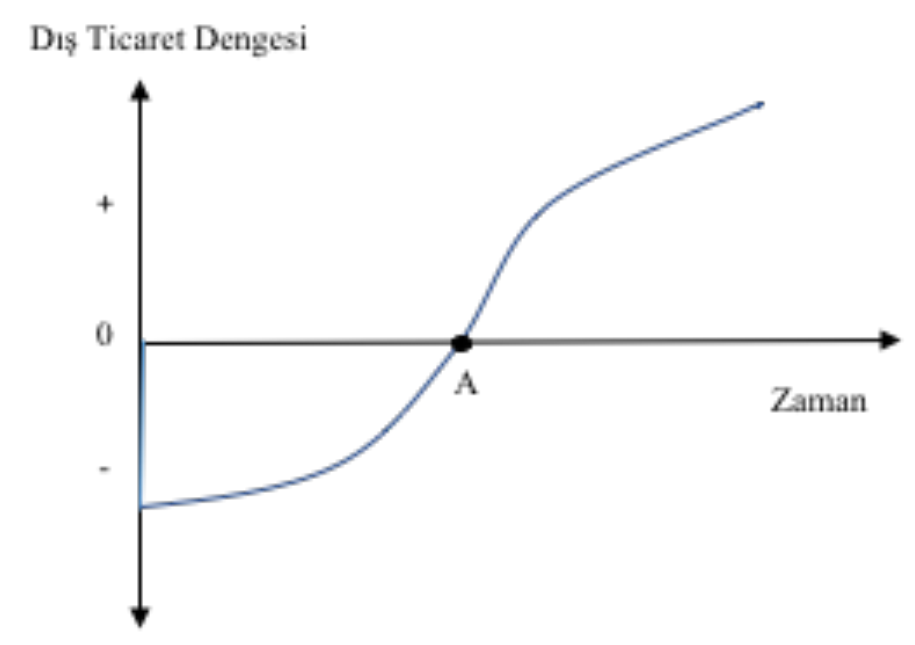

Şekil 8. J Ĕgrisi Etkisi

J-eğrisi etkisi Şekil 8'de gösterilmiştir. Ekonominin dış ticaret dengesi dikey eksende zaman ise yatay eksende yer almaktadır. Dış ticaretin başlangıçta dengede olduğu varsayılmıştır. Şekile göre devalüasyon veya kurdaki yükselmeyte birlikte diş ticaret dengesi başlangıçta bozulmuş, zaman geçtikçe söz konusu bozulma ortadan kalkmış ve A noktasında dış ticaret dengesi yeniden sağlanmıştır. Ardından durum tersine dönerek ekonomi nihayet dış ticaret fazlası vermeye başlamıştır. 


\section{Reel Faiz Oranı}

Mundell-Fleming modeline göre reel faiz oranındaki artış, ülke içine yönelik yabancı sermaye hareketlerini teşvik ederek ulusal para biriminin değer kazanmasına neden olur ve ithalat artışı yoluyla cari açık genişler.

Dönemler arası yaklaşım da reel faiz oranındaki değişmelerin cari denge üzerindeki etkilerini incelerken tüketim üzerine odaklanmaktadır. Buna göre reel faiz oranındaki değişmeler tüketimin dönemler arasında ikame edilmesine neden olmaktadır. Faiz oranındaki artış yurtiçi kredi talebinde ve iç talepte azalmaya yol açmakta, öte yandan tüketimin ertelenmesine neden olmakta ve tasarrufu teşvik etmekte ve böylece cari işlemler dengesi de iyileşmektedir. Aksine faiz oranının düşmesi, bugünkü tüketimin artmasına ve tasarrufların azalmasına neden olmakta, böylece cari açık da genişlemektedir. Nitekim literatürdeki ampirik çalışmalarda reel faiz oranındaki değişimin cari işlemler dengesini nasıl etkilediği konusunda görüş birliği yoktur (Narayan, 2009).

\section{Türkiye Ekonomisini Ele Alan Ampirik Çalışmalar}

Türkiye ekonomisi için cari açığın belirleyicileri birçok çalışmaya konu olmuştur. Türkiye'de cari açık temelde ekonomik büyüme, bütçe açığı döviz kuru, faiz oranları, petrol fiyatları ve dış ticaret hadleri gibi çeşitli makroekonomik değişkenle ilişkilendirilmiştir. Bu değişkenlerle cari açık arasındaki nedensellik ilişkileri farklı dönemler için çeşitli yöntemlerle araştırılmıştır. Tablo 1'de Türkiye ekonomisinde cari açı̆̆ın belirleyicilerine yönelik özet literatüre yer verilmiştir.

Tablo 1. Türkiye Ekonomisine Yönelik Literatür Özeti

\begin{tabular}{|c|c|c|c|}
\hline Çalışma & Dönem & Yöntem & Cari açığın belirleyicileri \\
\hline Erkılıç (2006) & 1987:Q1-2005Q4 & VAR & $\begin{array}{l}\text { Bir dönem önceki cari açık, } \\
\text { büyüme, reel döviz kuru }\end{array}$ \\
\hline Erbaykal (2007) & 1987:Q1-2006:Q3 & Toda-Yomato & Büyüme, reel döviz kuru \\
\hline Y1lmaz ve Akıncı (2012) & $1980-2010$ & Johansen & $\begin{array}{l}\text { GSYH, faiz oran1, döviz kuru, } \\
\text { doğrudan yatırımlar }\end{array}$ \\
\hline $\begin{array}{l}\text { Bayraktutan ve Demirtaş } \\
(2011)\end{array}$ & $1980-2006$ & Panel GLS & $\begin{array}{l}\text { Büyüme oranı, yatırımlar, kamu } \\
\text { harcamaları, dış ticaret haddi, dışa } \\
\text { açıklık, dünya faiz oranları }\end{array}$ \\
\hline Mangir (2012) & 1980-2011 & Johansen & Bütçe açığ 1 \\
\hline Kesikoğlu vd., (2013) & 1999-2009 & Panel VAR & Büyüme, faiz oranı, bütçe açığı \\
\hline Göçer (2013) & 1996:M1-2012:M1 & VAR & $\begin{array}{l}\text { Enerji ithalatı, enerji hariç dış } \\
\text { ticaret açığı, dış borç faiz } \\
\text { ödemeleri }\end{array}$ \\
\hline Çiftçi (2014) & 2001Q1-2012:Q3 & VAR & Büyüme, reel döviz kuru \\
\hline Bayar, Kılıç ve Arıca (2014) & 2000:Q4-2013Q4 & VAR & $\begin{array}{l}\text { Petrol fiyatları, doğrudan sermaye } \\
\text { yatırımları, portföy yatırımları, } \\
\text { kamu borç stoku }\end{array}$ \\
\hline Alioğulları vd., (2015) & 2003:Q2-2015:Q2 & GMM & Tüketici kredileri \\
\hline Yüksel (2016) & 1994:Q1-2014:Q4 & MARS & $\begin{array}{l}\text { Bir dönem önceki cari açık, } \\
\text { büyüme, faiz oranı }\end{array}$ \\
\hline Sönmezler vd. (2017) & 2003:M01-2015:M10 & Johansen & Reel döviz kuru \\
\hline Duman (2017) & 2003:Q1-2017:Q1 & VAR & Ekonomik büyüme \\
\hline Güneş ve Y1ldırım (2017) & 2005:Q4-2016:Q4 & ECM & \begin{tabular}{|l|} 
Taşıt kredileri, kurumsal krediler \\
\end{tabular} \\
\hline
\end{tabular}




\section{Veri Seti, Ekonometrik Yöntem ve Bulgular}

Çalışmada cari işlemler açığının nedenlerini açıklamak üzere tahmin edilecek model teorik ve ampirik literatür çerçevesinde eşitlik 11'de şu şekilde belirlenmiştir: $C A B=$ $\mathrm{F}(G D P, \mathrm{BUD}, E R, I R)$. Cari işlemler dengesini ( $c a b)$ temsil etmek üzere cari işlemler dengesinin GSYH’ya oranı modelde bağımlı değişken olarak kullanılmıştır. Ulusal geliri temsil etmek üzere zincirlenmiş hacim endeksine göre hesaplanan GSYH'nın doğal logaritması $(\operatorname{lrg} d p)$ kullanılmıştır. $\mathrm{Bu}$ değişken geniş anlamda ekonominin makroekonomik performansını göstermektedir. Ayrıca konjonktürel değişimlerin modelde kontrol edilmesine olanak tanımaktadır. Bütçe açığı göstergesi olarak genel bütçe dengesinin GSYH'ye oranı (bud), döviz kuru için TÜFE bazlı hesaplanan reel efektif döviz kuru endeksinin doğal logaritması (lreer) kullanılmıştır. Ekonomideki reel faiz oranının (rir) hesaplanmasında, bankalarca 3 aya kadar vadeli olarak açılan mevduatlara uygulanan ağırlıklı ortalama faiz oranı ve TÜFE'deki çeyreklik değişim oranları kullanılmıştır. Tahmin edilecek model basit regresyon biçiminde eşitlik 13 'te gösterilmiştir.

$$
c a b_{t}=\alpha_{0}+\alpha_{1} \operatorname{lrgdp_{t}}+\alpha_{2} \text { bud }_{t}+\alpha_{3} \text { reer }_{t}+\alpha_{4} r i r+e_{t}
$$

Model üç aylık frekanstaki veriler kullanılarak tahmin edilmiştir. Modeli tahmin etmek üzere tanımlanan değişkenlere ilişkin verilerin tamamı TCMB Elektronik Veri Dağıtım Sisteminden elde edilmiştir. Çalışmada kullanılacak bütçe dengesi verilerinin yeni yönteme göre 2006 yılından itibaren yayınlanmaya başlaması nedeniyle analizin kapsamı için 2006:Q1-2019:Q1 dönemi seçilmiştir.

\section{Birim Kök Testleri}

Türkiye ekonomisinde cari açık ile seçilen diğer değişkenler arasındaki dinamikleri incelemek amacıyla kullanılacak yöntemin belirlenebilmesi için öncelikle birim kök testleri gerçekleştirilmiştir. Değişkenlerin birim kök özelliklerini araştırmak üzere geleneksel ADF ve PP testleri kullanılmıştır.

Tablo 2. Augmented-Dickey-Fuller Birim Kök Testi Sonuçları

\begin{tabular}{|c|c|c|c|c|}
\hline & \multicolumn{2}{|c|}{ Düzey } & \multicolumn{2}{|c|}{ Birinci farklar } \\
\hline & Sabit & Sabit ve trend & Sabit & Sabit ve trend \\
\hline Cari denge (cab) & $-3.805(0)^{* * *}$ & $-3.900(1)^{* *}$ & & \\
\hline GSYH (lrgdp) & $-2.218(0)$ & $-5.650(0)^{* * *}$ & & \\
\hline Bütçe dengesi (bud) & $-6.154(1)^{* * *}$ & $-7.079(0)^{* * *}$ & & \\
\hline Reel döviz kuru (lreer) & $-1.149(0)$ & $-2.905(1)$ & $-8.903(0)^{* * *}$ & $-9.135(0) * * *$ \\
\hline Reel faiz oran1 (rir) & $-1.957(3)$ & $-2.082(0)$ & $-7.616(0)^{* * *}$ & $-7.540(0)^{* * *}$ \\
\hline
\end{tabular}

$* * * \% 1, * * \% 5 \mathrm{ve}^{* * *} \% 10$ anlamlllık düzeyinde sıfır hipotezinin reddedildiğini göstermektedir. 
Tablo 3. Phillips-Perron Birim Kök Testi Sonuçları

\begin{tabular}{lllll}
\hline & \multicolumn{2}{c}{ Düzey } & \multicolumn{2}{c}{ Birinci farklar } \\
\hline & Sabit & Sabit ve trend & Sabit & Sabit ve trend \\
\hline Cari denge (cab) & $-3.864 * * *$ & $-3.779^{* *}$ & & \\
GSYH (lrgdp) & -1.891 & $-5.457 * * *$ & & \\
Bütçe dengesi (bud) & $-6.982^{* * *}$ & $-7.130^{* * *}$ & & \\
Reel döviz kuru (lreer) & -0.993 & -2.720 & $-8.974 * * *$ & $-9.511^{* * *}$ \\
Reel faiz oran1 (rir) & -1.717 & -2.107 & $-7.632^{* * *}$ & $-7.556^{* * *}$ \\
\hline
\end{tabular}

$* * * 1, * * \% 5 \mathrm{ve}{ }^{* * *} \% 10$ anlamlllık düzeyinde sıfır hipotezinin reddedildiğini göstermektedir.

Serileri uygulanan ADF ve PP birim kökleri testleri neticesinde cari denge (cab), reel GSYH (lrgdp) ve bütçe dengesini (bd) ifade eden serilerin düzeylerinde durağan oldukları, reel döviz kuru (lreer) ve reel faiz oranını (rir) ifade eden serilerin ise birinci farklarında durağan oldukları tespit edilmiştir. Başka bir ifadeyle cari denge, GSYH ve bütçe dengesi serileri düzeylerinde durağan, I(0), reel döviz kuru ve reel faiz oranı serileri ise birinci dereceden bütünleşik, I(1)'dir. ADF ve PP birim kökleri testlerinin sonuçları birbirlerini desteklemektedir. Serilerin bazılarının düzeyinde durağan olmaması nedeniyle eşitlik 13'teki model En Küçük Kareler (EKK) yöntemi kullanılarak tahmin edilemez. Çünkü EKK tüm serilerin düzeyinde durağan olmasını gerektirir. Bu sonuçlar doğrultusunda farklı dereceden bütünleşik seriler arasında analiz yapmaya olanak tanıyan Autoregressive Distributed Lag Model (ARDL) yönteminin kullanılmasının uygun olduğuna karar verilmiştir. ARDL yönteminin başka bir avantajı da küçük örneklemlerde dahi tahmin performansının yüksek olmasıdır.

\section{ARDL Sınır Testi Yaklaşımı}

Değişkenler arasındaki eşbütünleşme ilişkileri incelenirken yaygın olarak Johansen eşbütünleşme testi uygulanır. Fakat Johansen yöntemi serilerin aynı dereceden durağan olmasını gerektirmektedir. Farklı dereceden durağan seriler arasındaki eşbütünleşme ilişkileri araştırılırken ARDL Sınır Testi yaklaşımı uygulanabilir. Eğer Sınır Testi sonucunda değişkenlerin eşbütünleşik olduğu tespit edilirse hem kısa dönem dinamiklerini gösteren ARDL modeli hem de uzun dönem dinamiklerini gösteren bir Hata Düzeltme (ECM) modeli tahmin edilebilir. Sınır Testi’ni gerçekleştirebilmek üzere belirlenen ARDL modeli aşağıdaki gibidir:

$$
\begin{aligned}
\Delta c a b=\alpha_{0}+ & \sum_{i=1}^{p} \alpha_{1 i} \Delta c a b_{t-i}+\sum_{i=0}^{q} \alpha_{2 i} \Delta \operatorname{lrg}_{t-i} \\
& +\sum_{i=0}^{r} \alpha_{3 i} \Delta b u d_{t-i}+\sum_{i=0}^{s} \alpha_{4 i} \Delta \text { lreer }_{t-i} \\
& +\sum_{i=0}^{t} \alpha_{5 i} \Delta \text { rir }_{t-i}+\theta_{1} \text { cab }_{t-1}+\theta_{2} \operatorname{lrgdp}_{t-1} \\
& +\theta_{3} \text { bud }_{t-1}+\theta_{4} \text { lreer }_{t-1}+\theta_{5} \text { rir }_{t-1}+u_{t}
\end{aligned}
$$

Denklemde $\Delta$ ile birinci fark işlemcisi; $\theta$ ile uzun dönem katsayıları; $u_{t}$ ile hata terimi temsil edilmektedir. Modelde yer alan p, q, r, s ve t ele alınan değişkenlerin gecikme uzunluklarını göstermektedir. Değişkenler arasında uzun dönem ilişkisi olup olmadığının belirlenebilmesi için yukarıdaki model OLS ile tahmin edilir. Optimum gecikme uzunluğunun belirlenmesinde 
AIC, HQ ve SB gibi bilgi kriterlerinden yararlanılır. Tahmin edilen modelde gecikmeli değişkenlerin birlikte anlamlı olup olmadığı $\mathrm{F}$ testi ile sınanır. F testi için oluşturulan sıfır hipotezi $\left(H_{0}\right)$ ve alternatif hipotez $\left(H_{1}\right)$ aşağıda sunulmuştur. Sıfır hipotezi, değişkenler arasında eşbütünleşmenin bir başka ifadeyle uzun dönemli ilişkinin bulunmadığını, alternatif hipotez ise değişkenler arasında uzun dönemli ilişkinin veya eşbütünleşmenin bulunduğunu ifade etmektedir.

$$
\begin{aligned}
& H_{0}: \theta_{1}=\theta_{2}=\theta_{3}=\theta_{4}=\theta_{5} \\
& H_{1}: \theta_{1} \neq \theta_{2} \neq \theta_{3} \neq \theta_{4} \neq \theta_{5}
\end{aligned}
$$

Modelin hesaplanmış olan F istatistik değeri Pesaran vd. (2001) tarafından belirtilen alt ve üst sınırlar ile karşılaştırılır. F istatistik değeri tabloda belirtilen alt sınırdan küçükse eşbütünleşmenin olmadığını ifade eden $H_{0}$ hipotezi reddedilmez, aksine F istatistik değeri üst sınırdan büyükse $H_{0}$ reddedilir ve modelde ele alınan değişkenlerin arasında uzun dönemli ilişkinin var olduğu sonucuna varılır. Hesaplanmış F istatistiği belirtilen alt ve üst sınırın arasında kalıyor ise karar verilemez, eşbütünleşme başka teknikler kullanılarak araştırılır.

Eşbütünleşme belirlendikten sonraki aşamada, ele alınan değişkenlerle bir hata düzeltme modeli belirlenir ve tahmin edilir. Bu çalışmada tahmin edilecek hata düzelme modeli aşağıdaki eşitlikte sunulmuştur.

$$
\begin{aligned}
\Delta c a b=\beta_{0}+ & \sum_{i=1}^{p} \beta_{1 i} \Delta c a b_{t-i}+\sum_{i=0}^{q} \beta_{2 i} \Delta \operatorname{lrgdp}_{t-i} \\
& +\sum_{i=0}^{r} \beta_{3 i} \Delta b u d_{t-i}+\sum_{i=0}^{s} \beta_{4 i} \Delta_{\text {lreer }} \text { t }_{t} \\
& +\sum_{i=0}^{t} \beta_{5 i} \Delta \text { rir }_{t-i}+\psi e c m_{t-1}+v_{i}
\end{aligned}
$$

Eşitlikte yer alan $\beta$ katsayıları kısa dönem dinamik katsayılardır. Hata düzeltme teriminin katsayısı, $\psi$, ekonomide kısa dönemde meydana gelebilecek bir şok karşısında modelin uzun dönem dengesine yeniden dönme hızını göstermektedir. Söz konusu katsayının istatistiksel olarak anlamlı ve negatif olması gerekmektedir. Uzun dönemli nedenselliğin mevcut olup olmadığı gecikmeli hata düzeltme teriminin katsayısının anlamlılığı ile tespit edilebilir. Katsayı t-testi ile sınanır. Bu katsayı anlamlı ise uzun dönemli nedenselliğin mevcut olduğu sonucuna varilır.

Model tahmin edildikten sonra modelde otokorelasyon ve değişen varyans sorununun olmadığının, model belirleme hatası yapılmadığının ve hata terimlerinin normal dağıldığının çeşitli tanısal testlerle ispatlanması gerekir. Ayrıca modelin istikrarlı olup olmadığının Brown vd. (1975)'nin geliştirdiği Birikimli Toplam (CUSUM) ve Birikimli Kareler Toplamı (CUSUMSQ) testleri ile sınanması önerilmektedir. Hesaplanmış olan CUSUM ve CUSUMSQ istatistiklerinin grafikleri \%5 anlamlılık düzeyini gösteren kritik sınırlar içerisinde kalıyorsa modelin istikrarlı olduğu sonucuna varılır. 


\section{Ampirik Sonuçlar}

Gerçekleştirilen birim kök testleri neticesinde değişkenlerin I(0) ve I(1) özelliği taşıdıkları, hiç birinin I(2) özelliği taşımadığı tespit edilmiş ve bu nedenle uzun dönem cari açık dinamiklerini incelemek üzere ARDL sınır testi yönteminin uygun olduğuna karar verilmiştir.

Optimum gecikme uzunluğunun belirlenmesinde Akaike bilgi kriterinden (AIC) yararlanılmıştır. Kısıtlı gözlem sayısı (53) nedeniyle maksimum gecikme uzunluğu olarak 5 gecikme seçilmiştir. Eşbütünleşme ilişkisini araştırmak üzere gerçekleştirilen ARDL Sınır Testi sonuçları aşağıdaki tabloda yer almaktadır.

Tablo 4. ARDL Sınır Testi Sonuçları

\begin{tabular}{lcc}
\hline Model: $c a b=f($ lrgdp, bud, lreer, rir $)$ & \multicolumn{2}{c}{ Kritik Değerler } \\
\hline F istatistiği: 10.001 & Alt Sınır I(0) & Üst Sınır I(1) \\
\%1 anlam düzeyi & 3.74 & 5.76 \\
$\% 5$ anlam düzeyi & 2.86 & 4.01 \\
\%10 anlam düzeyi & 2.45 & 3.52 \\
\hline
\end{tabular}

Tabloda yer alan F testi sonuçlarına göre hesaplanan F istatistiği (10.001) \%1 anlamlılık düzeyini belirten kritik değerin üst sınır değeri olan 5.76'dan büyüktür. Bu sonuca göre değişkenler arasında eşbütünleşme olduğu ve aralarında uzun dönemli ilişkinin mevcut olduğu sonucuna varılmıştır. Buna göre, kısa dönemde değişkenlerde şoklar meydana gelebilir ancak model zaman içerisinde uzun dönem dengesine yakınsamaktadır. Eşbütünleşme tespit edildiği için hem uzun dönem hem de kısa dönem modeli tahmin edilebilir. Tahmin edilen ARDL modeline ait kısa dönem dinamik parametreleri, uzun dönem tahmin sonuçları ve tanısal test istatistikleri aşağıdaki tabloda sunulmuştur.

Tablo 5. Uzun ve Kısa Dönem Tahmin Sonuçları (Bağımlı değişken: cab)

\begin{tabular}{|c|c|c|c|}
\hline & Katsayı & $t$ istatistiğ & Olasılık \\
\hline \multicolumn{4}{|c|}{ Hata düzeltme katsayısı } \\
\hline ecm $(-1)$ & $-0.323 * * *$ & -2.85 & 0.008 \\
\hline \multicolumn{4}{|c|}{ Uzun dönem sonuçlart } \\
\hline lrgdp & -0.153 & -1.62 & 0.114 \\
\hline bud & $4.532 *$ & 1.93 & 0.063 \\
\hline lreer & $-0.346 * *$ & -2.06 & 0.047 \\
\hline rir & $-0.006^{*}$ & -1.71 & 0.098 \\
\hline \multicolumn{4}{|c|}{ Kısa dönem sonuçlart } \\
\hline $\mathrm{d}(\mathrm{cab}(-1))$ & $-0.380 * *$ & -2.46 & 0.020 \\
\hline $\mathrm{d}(\mathrm{cab}(-2))$ & -0.151 & -1.19 & 0.242 \\
\hline $\mathrm{d}(\mathrm{cab}(-3))$ & -0.220 & -1.64 & 0.112 \\
\hline d(lrgdp) & $-0.161 * * *$ & -2.85 & 0.008 \\
\hline $\mathrm{d}(\operatorname{lrgdp}(-1))$ & $-0.149 * *$ & -2.74 & 0.010 \\
\hline $\mathrm{d}(\operatorname{lrgdp}(-2))$ & $-0.312 * * *$ & -7.16 & 0.000 \\
\hline $\mathrm{d}(\operatorname{lrgdp}(-3))$ & $-0.277 * * *$ & -4.49 & 0.000 \\
\hline $\mathrm{d}$ (bud) & $-1.389 * * *$ & -3.93 & 0.000 \\
\hline $\mathrm{d}(\operatorname{bud}(-1))$ & $-1.145^{* * *}$ & -3.56 & 0.001 \\
\hline $\mathrm{d}(\operatorname{bud}(-2))$ & $-0.917 * * *$ & -3.73 & 0.001 \\
\hline $\mathrm{d}(\operatorname{bud}(-3))$ & $-0.560 * * *$ & -3.57 & 0.001 \\
\hline $\mathrm{d}$ (lreer) & 0.057 & 1.60 & 0.120 \\
\hline sabit & $1.510 * * *$ & 2.90 & 0.007 \\
\hline
\end{tabular}

${ }^{* * *} \% 1,{ }^{* *} \% 5 \mathrm{ve}{ }^{* * *} \% 10$ anlamlılık düzeyinde sıfır hipotezinin reddedildiğini göstermektedir. 
Gecikmeli hata düzeltme katsayısı (ecm(-1)) negatif ve anlamlıdır. Elde edilen bu katsayı (0.323) modelde ele alınan değişkenler arasında uzun dönemli nedensellik ilişkisinin mevcut olduğu konusunda bilgi sağlamaktadır. Bu katsayı mutlak anlamda büyüdükçe daha hızlı bir düzeltme süreci gerçekleşir. Katsayı bir önceki dönemde gerçekleşen şokun yaklaşık olarak \%32'sinin cari ayda giderilerek modelin uzun dönemlik dengesine doğru hareket ettiğini göstermektedir. Buna göre modeldeki şokların etkileri bir yıldan kısa sürede giderilmektedir. Uzun dönem katsayılarına göre cari işlemler dengesinin temel belirleyicileri bütçe dengesi (bud), reel döviz kuru (lreer) ve reel faiz oranıdır (rir). Uzun dönemde cari açık ile reel GSYH arasında anlamlı bir ilişki tespit edilememiştir.

Bütçe açığının uzun dönemlik etkisi beklendiği gibi pozitiftir. Pozitif katsayı bütçe açı̆̆ı azaldıkça cari açığın da azaldığını göstermektedir. Bu bulgu cari açığın bütçe açıklarından kaynaklandığını ifade eden ikiz açıklar hipotezini desteklemektedir. İki denge unsuru arasında bir ilişki olmadığını ifade eden Ricardocu denklik hipotezinin ise Türkiye ekonomisi için geçerli olmadığını göstermektedir.

Reel döviz kuru ile cari işlemler dengesi ilişkisi uzun dönemde negatif ve anlamlı olarak tespit edilmiştir. Buna göre Türk lirasının değer kazanması cari işlemler dengesini olumsuz yönde etkilemektedir. TL'deki değer artışları, ithal mallarının TL cinsinden ucuzlamasına ve toplam ithalatın artmasına neden olur. Değer artışları aynı anda Türkiye'nin ihraç mallarının yabancıların nezdinde pahalı hale gelmesine ve ihracatın azalmasına neden olmaktadır.

Reel faiz oranı ile cari işlemler dengesi arasındaki uzun dönem ilişkisi negatif ve anlamlıdır. Reel faiz oranındaki artışlar cari işlemler dengesini olumsuz etkilemektedir. Bu durum teorik beklenti ile uyumludur. Reel faiz oranlarının artması Türkiye'ye yönelik yabancı sermaye akımlarını artırmakta bu da ekonomide döviz bolluğuna neden olmaktadır. Artan döviz arzı TL'nin yabancı paralar karşısında değer kazanmasına neden olarak ithalatı artırmakta ihracatı azalmaktadır, böylece dış ticaret dengesi olumsuz etkilenmekte ve cari açık derinleşmektedir. Kısa dönem katsayıları modelin uzun dönem dengesine yakınsama dinamiklerini göstermektedir. ARDL modelindeki kısa dönem katsayılar tıpkı EKK yöntemindeki gibi “ceteris paribus" etkileri gösterir.

Uzun dönemde etkisiz olan GSYH, kısa dönemde cari işlemler dengesi üzerinde etkilidir. Elde edilen katsayılara göre kısa dönemde büyüme ile cari işlemler dengesi arasında negatif bir ilişki mevcuttur. Bu durum kısa vadeli sermaye girişleri ile büyüme dinamikleri arasında önemli bir ilişki olduğunu ortaya koymaktadır.

Reel döviz kurunun cari işlemler dengesi üzerindeki etkisinin uzun dönemde pozitif iken kısa dönemde negatif olması J eğrisi etkisinin Türkiye'de geçerli olduğunu ortaya koymaktadır. J eğrisi etkisine göre devalüasyon veya ulusal paradaki değer kayıplarının hemen ardından cari işlemler dengesinde kısa süreli bir bozulma gerçekleşir. Fakat zaman içerisinde bu bozulma giderilerek cari işlemler açı̆̆ı hızla azalır. Hata düzeltme modeli ayrıca reel faiz oranlarının kısa dönemde cari işlemler dengesi üzerinde anlamlı bir etkisi olmadığını göstermektedir. 
Son olarak tahmin edilen ARDL modeline ilişkin çeşitli tanısal ve istikrar testler Tablo 6'da yer almaktadir.

Tablo 6. Tanisal Testler

\begin{tabular}{lcc}
\hline Test & Test istatistiği & Olasılık \\
\hline Normallik (JB) & 0.884 & 0.642 \\
Ramsey RESET & 1.240 & 0.313 \\
Değişen varyans (White testi) & 49.00 & 0.432 \\
Otokorelasyon (LM testi) & 0.062 & 0.803 \\
CUSUM & \multicolumn{2}{c}{ İstikrarlı } \\
CUSUMsq & \multicolumn{2}{c}{ İstikrarlı } \\
\hline
\end{tabular}

Uygulanan testlere göre modelde ekonometrik bir sorun mevcut değildir. Yürütülen testlerin sıfır hipotezleri sırasıyla, Jarque-Bera testinde hata terimlerinin normal dağıldığını, Ramsey RESET testinde modelin fonksiyonel biçiminin doğru belirlendiğini, LM testinde modelde otokorelasyon olmadığını ve White testinde hata terimlerinin varyanslarının değişmediğini ifade etmektedir. Sayılan bu testlerin hiçbirinde sıfır hipotezi reddedilememiştir. Gerçekleştirilen testlere göre, modelde hata terimleri normal dağılıma sahip, model fonksiyonel olarak doğru bir biçimde belirlenmiş ve modelde otokorelasyon ve değişen varyans mevcut değildir.
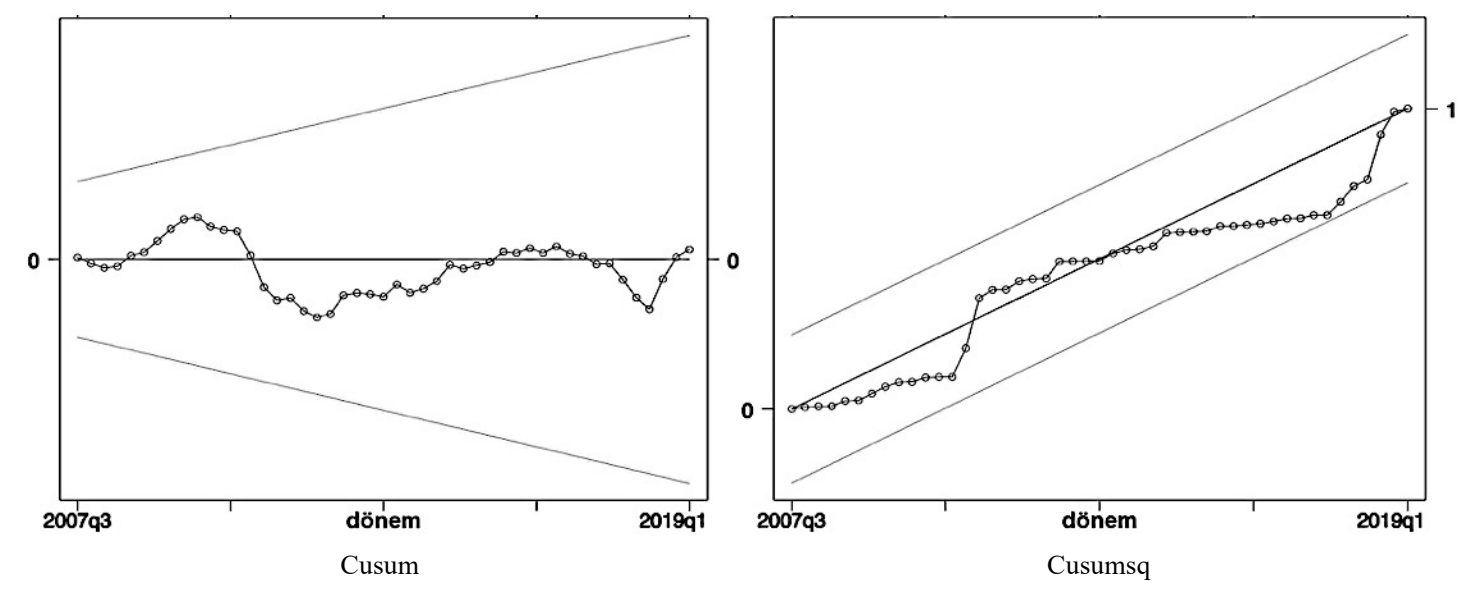

Şekil 9. Cusum ve Cusumsq İstikrar Testleri

Yapısal istikrarı test edebilmek için modele CUSUM ve CUSUMSQ istikrar testleri uygulanmıştır. Şekil 9'da yer alan CUSUM ve CUSUMSQ istatistikleri kritik değerlerin arasında kalmaktadır. Bu durum Hata Düzeltme Modelinde elde edilen katsayıların istikrarlı olduğunu, tahmin edilen dönem içerisinde sabit bir düzen içerisinde olduğunu ve beklenmeyen etkilerin ortaya çıkmadığını göstermektedir. Buna göre, model politika tasarımlarında kullanmaya uygundur. 


\section{Sonuç}

Türkiye ekonomisinde özellikle 2001 krizi sonrası dönemde cari açık giderek derinleşmiş ve kalıcı hale gelmiştir. Ekonomide neden olduğu kırılganlıklar ve nedeniyle cari açık hem sıkça takip edilen bir gösterge hem de önemli bir endişe kaynağı haline gelmiştir. Bu bakımdan Türkiye ekonomisinde cari açığın yapısının, dinamiklerinin ve nedenlerinin araştırılması önemlidir. Çalışmada Türkiye ekonomisinde cari işlemler açı̆̆ına neden olan temel faktörler hem betimsel istatistiklerle hem de ekonometrik yöntemlerle araştırılmıştır.

Türkiye ekonomisinde cari açık temelde dış ticaret açığından kaynaklanmakta, cari açıktaki dalgalanmalara dış ticaret açığındaki değişimler neden olmaktadır. İthalat çalışmada ele alınan dönem boyunca ihracatın üzerinde gerçekleşmiştir. Sanayi üretiminde ara malı ithalatına yoğun bir bağımlılığı olan Türkiye'de ithalatın çok önemli bir kısmını ara malları teşkil etmektedir. Buna karşın ihracat yapısı içerisinde ara mallarının payı daha küçük ve tüketim mallarının payı yüksektir. Öte yandan hizmetler ve ikincil gelir dengesi dış denge üzerinde olumlu etkiler yaratmakta dış ticaret açığının cari işlemler dengesi üzerinde yarattığı olumsuz etkinin bir kısmını gidermektedirler. Birincil gelir dengesi ise cari açığı derinleştirmektedir. Özellikle yabancı yatırımlara ödenen kâr payı ve faiz ödemelerinden oluşan birincil gelir dengesinin büyüklüğü cari açığın finansman maliyetinin oldukça yüksek olduğunu göstermektedir.

Büyüme ile cari açık Türkiye'de aynı yönlü hareket etmektedir ve bu durum Türkiye'de büyüme dinamikleri ve dış finansman girişleri arasında önemli bir ilişki olduğunu ortaya koymaktadır. Dış finansman girişleri Türkiye'de ekonomik büyümeyi teşvik etmekte fakat finansman girişlerinde yavaşlama olduğunda büyüme hızı yavaşlamaktadır. Bu durum ekonomiyi kırılgan hale getirmektedir. Tasarruf, yatırım ve cari denge ilişkisi incelendiğinde ise cari açı̆̆ın yatırımlarla birlikte hareket ettiği, tasarrufların ise dönem boyunca istikrarlı olduğu tespit edilmiştir. Yatırımlar ile cari açık arasındaki bu ilişki ekonomik büyümenin dış finansmana bağımlılı̆̆ 1 konusunda ayrı bir bulgudur.

Ampirik analizde dönemler arası yaklaşım ve esneklikler yaklaşımı çerçevesinde belirlenen sentez bir ekonometrik model tahmin edilerek, çeşitli makroekonomik değişkenler ile cari açık arasındaki kısa ve uzun dönemlik ilişkiler araştırılmıştır. Çalışma kapsamında tahmin edilen modelin güvenirliği ve politika tasarımlarında kullanıma uygunluğu çeşitli testlerle sınanmış ve uygun olduğuna karar verilmiştir. Elde edilen bulgulara göre uzun dönemde bütçe açı̆̆ı, döviz kuru ve faiz oranları cari işlemler dengesi üzerinde etkiliyken kısa dönemde ulusal gelir ve bütçe açı̆̆ı etkili olmaktadır.

Kısa dönemde ulusal gelir ile cari işlemler dengesi arasında tespit edilen ters yönlü ilişki, kısa dönem büyüme dinamiklerinin dış finansmana bağlı olduğunu ortaya koymaktadır. Bütçe açı̆̆ ile cari denge arasında hem kısa hem de uzun dönemde tespit edilen negatif yönlü ilişki ise Türkiye'de ele alınan dönem için Ricardocu Denklik Hipotezi karşısında İkiz Açık Hipotezinin geçerli olduğunu göstermektedir. Uzun dönemde reel efektif döviz kuru ile cari denge arasında negatif bir ilişki tespit edilmiştir. Bu durum TL’nin değer kazandığı dönemlerde cari açı̆̆ın arttığını, ulusal paradaki değer kayıplarının ise cari açı̆̆ı giderdiğini göstermektedir. Bu süreç 
daha çok ithalat üzerinden gerçekleşmektedir. Öte yandan bu ilişkinin kısa dönemde pozitif yönlü olması ise J-eğrisi etkisinin Türkiye ekonomisinde geçerliliği hakkında bilgi sağlamaktadır. Faiz oranı ile cari denge arasında ise uzun dönemde negatif bir ilişki tespit edilmiştir, bu bulgu sermaye girişlerinin faiz oranlarındaki değişimlere tepki verdiğini, sermayeye daha yüksek getiri vadedildiğinde cari açı pahasına ekonomiye finansman girişlerinin arttığını göstermektedir.

Sonuç olarak, dış ticaret yapısı içerisinde ara malı ithalatının payını azaltacak tarım ve sanayi politikalarının izlenmesi ve mümkün olan girdilerin yurt içinde üretilmesinin teşvik edilmesi, toplam ithalatı azaltarak cari açığın azalmasına yardımcı olabilir. Ayrıca enerjide dışa bağımlılığı azaltmak üzere alternatif ve yenilenebilir enerji kaynaklarına önem verilmesi dış ticaret açığının azalmasını sağlayacak ve enerji fiyatlarının cari denge üzerindeki etkisini zayıflatacaktır. Çalışmada tespit edilen bütçe dengesinin cari denge üzerindeki aynı yönlü etkisi nedeniyle kamuda mali disiplini artıracak politikaların izlenmesi ve vergi kayıplarının en aza indirilmesi cari açığın azaltılması konusunda önemlidir. Ayrıca dış finansmana olan bağımlılı̆̆ azaltmak üzere tasarruf özendirici politikaların izlenmesi, büyüme ile sermaye girişleri arasındaki bağlantıyı zayıflatarak hem büyümeyi daha istikrarlı hale getirebilir hem de dış finansmanın maliyetini azaltarak birincil gelir dengesinin cari denge üzerindeki olumsuz etkisini nispeten giderebilir. Türkiye'ye yönelik sermaye hareketlerinde kısa vadeli yatırımların yüksek payı, cari açığın neden olduğu kırılganlığın düzeyini artırmaktadır. Dış kaynak girişlerinde doğrudan yatırımların ağıllı̆̆ını artıracak politikaların izlenmesi hızlı sermaye çıkışlarının neden olabileceği olumsuzlukları azaltacaktır. Sermaye girişlerinde kısa vadeli yatıımların payının azalmasının cari açığın neden olduğu kırılganlıkları ne derece gidereceği başka bir çalışmanın konusu olabilir.

\section{Kaynakça}

Alioğulları, Z. H., Başkaya, Y. S., Bulut, Y. E., ve Kılınç, M. (2015). Türkiye'de Tüketici Ve Ticari Kredilerin Cari Açıkla Ilişkisi. TCMB Ekonomi Notları, 19, 1-13.

Appleyard, D. R., ve Field, A. J. (2015). International Economics (18th ed.). New York: McGrawHill/Irwin.

Bayar, Y., Kılıç, C., ve Arıca, F. (2014). Türkiye’de Cari Açığın Belirleyicileri. C. Ü. İktisadi ve İdari Bilimler Dergisi, 15(1), 451-472.

Bayraktutan, Y., ve Demirtaş, I. (2011). Gelişmekte Olan Ülkelerde Cari Açığın Belirleyicileri: Panel Veri Analizi. Kocaeli Üniversitesi Sosyal Bilimler Enstitüsü Dergisi, 2(22), 1-28.

Blanchard, O., \& Milesi-Ferretti, G. M. (2012). (Why) should current account balances be reduced?. IMF Economic Review, 60(1), 139-150.

Boratav, K. (2015). Türkiye İktisat Tarihi, 1908-2007 (12th ed.). Ankara: Imge Kitabevi.

Brissimis, S. N., Hondroyiannis, G., Papazoglou, C., Tsaveas, N. T., \& Vasardani, M. A. (2012). Current Account Determinants and External Sustainability in Periods of Structural Change. Economic Change an Restructuring, 45(1), 71-95. 
Brown, R. L., Durbin, J., ve Evans, J. M. (1975). Techiniques for Testing the Constancy of Regression Relations Over Time. Journal of the Royal Statistical Society, 37, 149-163.

Bussière, M., Fratzscher, M., ve Müller, G. J. (2010). Productivity shocks, budget deficits and the current account. Journal of International Money and Finance, 29(8), 1562-1579.

Calderón, C., Chong, A., ve Loayza, N. (1999). Determinants of Current Account Deficits in Developing Countries. Working Papers Central Bank of Chile, 51.

Calderón, C., Chong, A., ve Zanforlin, L. (2007). Current Account Deficits in Africa: Stylized Facts and Basic Determinants. Economic Development and Cultural Change, 56(1), 191221.

Catão, L. A., \& Milesi-Ferretti, G. M. (2014). External Liabilities and Crises. Journal of International Economics, 94(1), 18-32.

Chinn, M., ve Prasad, E. (2003). Medium-term Determinants of Current Accounts in Industrial and Developing Countries: An Empirical Exploration. Journal of International Economics, 59(1), 47-76.

Ciocyte, O., ve Rojas-Romagosa, H. (2015). Literature Survey on the Theorotical Explanations and Empirical Determinants of Current Account Balances. CPB Netherlands Bureau for Economic Policy Analysis, Background Document, April.

Çiftçi, N. (2014). Türkiye'de Cari Açı, Reel Döviz Kuru ve Ekonomik Büyüme Arasındaki Ilişkiler: Eş Buitünleşme Analizi. Anadolu Üniversitesi Sosyal Bilimler Dergisi, 14(1), 129142 .

Duman, Y. K. (2017). Türkiye'de Cari İşlemler Dengesi ve Ekonomik Büyüme Arasındaki İlişki. Sakarya İktisat Dergisi, 6(4), 12-28.

Erbaykal, E. (2007). Türkiye'de Ekonomik Büyüme ve Döviz Kuru Cari Açı Üzerinde Etkili Midir? Bir Nedensellik Analizi. ZKÜ Sosyal Bilimler Dergisi, 3(6), 81-88.

Erkılıç, S. (2006). Türkiye'de Cari Açı̆̆ın Belirleyicileri. TCMB Uzman Yeterlilik Tezi.

Feldstein, M. (1985). American Economic Policy and the World Economy. Foreign Affairs, 63(5), 995-1008.

Feldstein, M. (1987). Correcting the Trade Deficit. Foreign Affairs, 65(4), 795-806.

Glick, R., ve Rogoff, K. (1995). Global Versus Country-Specific Productivity Shocks and the Current Account. Journal of Monetary Economics, 35(1), 159-192.

Göçer, İ. (2013). Türkiye'de Cari Açı̆̆ın Nedenleri, Finansman Kalitesi ve Sürdürülebilirliği: Ekonometrik Bir Analiz. Eskişehir Osmangazi Üniversitesi İktisadi ve İdari Bilimler Dergisi, 8(1), 213-242.

Granger, C. W. J. (1969). Investigating Causal Relations by Econometric Models and Crossspectral Methods, Econometrica, 37(3), 424-438.

Güneş, S., \& Yıldırım, C. (2017). Kredi Genişlemesi ile Cari Açık Arasındaki İlişki: Türkiye Örneği. Aydın İktisat Fakültesi Dergisi, 2(1), 43-60.

Hasanov, F., ve Senhadji, A. (2008). Macroeconomic Balance Approach and Assessment of Exchange Rate Misalignments. In "Assessment of Exchange Rates" Report, East and Central Asia Department, IMF.

Husted, S., ve Melvin, M. (2013). International Economics (9th ed.). New Jersey: Pearson Education Inc. 
International Monetary Fund. (2013). External Balance Assessment (EBA) Methodology: Technical Background. Research Department, IMF. Washington.

Karluk, S. R. (2009). Uluslararası Ekonomi (9th ed.). İstanbul: Beta.

Kesikoğlu, F., Yıldırım, E., ve Çeştepe, H. (2013). Cari Açığın Belirleyicileri: 28 OECD Ülkesi için Panel Var Analizi. A广்BÜ - İIBF Ekonomik ve Sosyal Araştırmalar Dergisi, 9(2), 15-34.

Lee, J., Milesi-ferretti, G. M., Ostry, J., Prati, A., ve Ricci, L. A. (2008). Exchange Rate Assessments: CGER methodologies. Occasional Papers, IMF, 261.

Mangır, F. (2012). Türkiye için Ikiz Açıklar Hipotezi Testi (1980-2011). Ömer Halisdemir Üniversitesi İktisadi ve İdari Bilimler Fakültesi Dergisi, 5(2), 136-149.

Narayan, S. (2009). A survey on Dynamics of Current Account Imbalances. The Indian Economic Journal, 57(3), 3-26.

Obstfeld, M., ve Rogoff, K. (1994). The intertemporal approach to the current account. National Bureau of Economic Research Working Paper, 4893.

Obstfeld, M., ve Rogoff, K. S. (2002). Foundations of International Macroeconomics. Massachusetts: MIT PRess.

Özmen, E. (2014). Reel Döviz Kuru ve Türkiye Dış Ticaret Dinamikleri. Ekonomik Araştrma Forumu, WP/14/12.

Pesaran, M. H., Shin, Y., ve Smith, R. J. (2001). Bounds Testing Approaches to the Analysis of Level Relationships. Journal of Applied Econometrics, 16(3), 289-326.

Pugel, T. A. (2016). International Economics (16th ed.). New York: Mc Graw Hill Education.

Salvatore, D. (2006). Twin Deficits in the G-7 Countries and Global Structural Imbalances. Journal of Policy Modeling, 28(6), 701-712.

Salvatore, D. (2013). International Economics (11th ed.). New Jersey: John Wiley ve Sons, Inc.

Seyidoğlu, H. (2017). Uluslararası İktisat: Teori, Politika ve Uygulama (21st ed.). İstanbul: Güzem Can, No:32.

Sönmezler, G., Akduğan, U., ve Gündüz, İ. O. (2017). Türkiye’de Cari Açı Sorununun Reel Döviz Kuru ve İhracatın İthalata Bağımlılı̆̆ Açısından Değerlendirilmesi. Maliye ve Finans Yazıları, 108, 106-120.

Stokjov, A. (2016). A Survey of Competing Theoretical Approaches to Current Account Determination. CEA Journal of Economics, 1(1), 19-33.

YASED. (2011). Türkiye’nin Cari Açığı: Makro ve Mikro Açıdan Nedenleri ve Çözüm Önerileri. (Erişim Tarihi:

25.01.2018). http://www.yased.org.tr/webportal/English/insight_yased/Documents/YASED_Cari_Ac ik_Ra poru_2012.pdf

Yılmaz, Ö., Akıncı, M. (2012). Türkiye'de Cari Açıkların Belirleyicileri: Bir Zaman Serisi Analizi. TISK Academy/TISK Akademi, 7(14).

Yüksel, S. (2016). Türkiye'de Cari İşlemler Açığının Belirleyicileri: Mars Yöntemi ile Bir İnceleme. Bankacılar Dergisi, 96, 102-121. 